\title{
A/M Area DNAPL Characterization Report for Cores Collected in 2Q99
}

by

K. M. Vangelas

Westinghouse Savannah River Company

Savannah River Site

Aiken, South Carolina 29808

J. V. Noonkester

B. B. Looney

J. L. Simmons

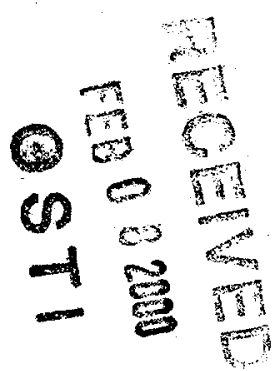

S. L. Baxley

This paper was prepared in connection with work done under the above contract number with the U. S. Department of Energy. By acceptance of this paper, the publisher and/or recipient acknowledges the U. S. Government's right to retain a nonexclusive, royalty-free license in and to any copyright covering this paper, along with the right to reproduce and to authorize others to reproduce all or part of the copyrighted paper. 


\section{DISCLAIMER}

This report was prepared as an account of work sponsored by an agency of the United States Government. Neither the United States Government nor any agency thereof, nor any of their employees, makes any warranty, express or implied, or assumes any legal liability or responsibility for the accuracy, completeness, or usefulness of any information, apparatus, product or process disclosed, or represents that its use would not infringe privately owned rights. Reference herein to any specific commercial product, process or service by trade name, trademark, manufacturer, or otherwise does not necessarily constitute or imply its endorsement, recommendation, or favoring by the United States Government or any agency thereof. The views and opinions of authors expressed herein do not necessarily state or reflect those of the United States Government or any agency thereof.

This report has been reproduced directly from the best available copy.

Available for sale to the public, in paper, from: U.S. Department of Commerce, National Technical Information Service, 5285 Port Royal Road, Springfield, VA 22161, phone: (800) 553-6847, fax: (703) 605-6900 email: orders@ntis.fedworld.gov online ordering: http://www.ntis.gov/ordering.htm

Available electronically at http://www.doe.gov/bridge Available for a processing fee to U.S. Department of Energy and its contractors, in paper, from: U.S. Department of Energy, Office of Scientific and Technical Information, P.O. Box 62, Oak Ridge, TN 37831-0062, phone: (865)576-8401, fax: (865)576-5728

email: reportseadonis.osti.gov 


\section{DISCLAIMER}

Portions of this document may be illegible in electronic image products. Images are produced from the best available original document. 
WSRC-TR-99-00468

August 1999

Revision 0

\section{A/M Area DNAPL Characterization Report}

\section{For}

Cores Collected in 2Q99

August 1999

Westinghouse Savannah River Company

Savannah River Site

Aiken, South Carolina 29808

Prepared for the United States Department of Energy under Contract No. DE-AC09-96-SR18500 


\title{
A/M Area DNAPL Characterization Report \\ For \\ Cores Collected in 2 Q99
}

\author{
K. M. Jerome \\ J. V. Noonkester \\ B. B. Looney \\ J. L. Simmons \\ S. L. Baxley
}

\section{U.S. Department of Energy \\ Westinghouse Savannah River Company \\ Savannah River Technology Center}

Savannah River Site

Aiken, SC 29808

operated by:

Westinghouse Savannah River Company

For the U.S. Department of Energy under Contract No. DE-AC09-96-SR18500 


\section{Table of Contents}

\begin{tabular}{lr}
\multicolumn{1}{c}{ Figures } & 1 \\
\multicolumn{1}{c}{ Tables } & 1 \\
Sumpendices & 1 \\
Background & 2 \\
Selection of Drilling Locations & 3 \\
Field Activities & 4 \\
Results of Subsurface Investigations & 6 \\
Evaluation of Results & 7 \\
Future Work & 13 \\
References & 15 \\
&
\end{tabular}

\section{Figures}

Figure 1. Location Map of FY99 Borings to Support Investigation of DNAPL Sources in the A/M Area...5 Figure 2. Depth Concentration Profile for Boring MRS 26, drilled at a $45^{\circ}$ angle beneath inlet to M-Area Basin

Figure 3. Depth Concentration Profile for Boring MRS 27, drilled at a $45^{\circ}$ angle from southern side of MArea Basin to center of basin

Figure 4. Depth Concentration Profile for Boring MRS 28, vertical boring adjacent to northern side of M-

Area Basin

Figure 5. Lithology Key for Depth Concentration Profiles and Lithology Profiles.

\section{Tables}

Table 1. Location Data for 2Q99 Borings to Support Investigation of DNAPL Sources at the M-Area Basin

Table 2. Identification of Elevations at which DNAPL and suspect DNAPL concentrations were reported for borings from the FY99 DNAPL investigations at the M-Area Basin

\section{Appendices}

Appendix A. Depth Concentration Information

Table A-1. Depth Concentration Profile for Soil Boring MRS26. Drilled at a $45^{\circ}$ angle from the north side of the M-Area Basin to below the inlet. A-11 Table A-2. Depth Concentration Profile for Boring MRS27. Drilled at a $45^{\circ}$ angle from the south side of the M-Area Basin to the center A-14 Table A-3. Depth Concentration Profile for Boring MRS28. Drilled vertically at a location between the M-Area Basin and the In Situ Oxidation Demonstration Location (MOX well series). A-15 


\section{Summary}

Drilling activities were conducted in $2 \mathrm{Q} 99$ in the $\mathrm{A} / \mathrm{M}$ Area to further delineate the soil contamination and potential areas of dense non-aqueous phase liquids (DNAPL) below the water table emanating from the M-Basin. The purpose of the work was to further understand the subsurface contaminant distribution and to identify locations below the water table where aggressive DNAPL remediation technologies should be pursued. This work consisted of using roto-sonic drilling to complete three borings to the top of the Green Clay confining unit. Results of the drilling activities indicate a potential source of DNAPL beneath the M-Area Basin may be of sufficient quantity to support implementation of an aggressive groundwater remediation technology. Additional angle drilling beneath the basin and vertical drilling adjacent to the basin should be pursued to verify and quantify this initial finding. Tetrachloroethylene (PCE) and trichloroethylene (TCE ) were found at concentrations ranging from below detection to $200 \mathrm{ppm}$ and below detection to $23 \mathrm{ppm}$, respectively. The highest concentrations are located within a clay/sandy clay zone at elevations ranging from $215 \mathrm{ft}$ msl to $270 \mathrm{ft} \mathrm{msl}(80 \mathrm{ft}$ to $135 \mathrm{ft}$ depth below ground surface).

Data collected at the M Area Settling Basin in FY99 provide additional evidence that contaminants are migrating toward the west/southwest from the basin along structural "depressions" on the surfaces of low permeability intervals. The concentrations measured in these cores indicate that the highest DNAPL source concentrations are present immediately adjacent to the source and do not indicate that a large volume of DNAPL is present at the locations further from the source. The data collected in FY99 corroborate the original data and indicate that a significant amount of PCE and TCE may still be located directly below the basin inlet. 


\section{Background}

The A/M Area, a reactor fuel and target assembly area of the Savannah River Site, discharged approximately 3.5 million pounds of waste industrial solvents (primarily trichloroethylene, TCE, and tetrachloroethylene, PCE, with much lesser amounts of trichloroethane, TCA) from the 1950's to early 1980's. These discharges occurred at two locations - the A-014 Outfall and the M Area Settling Basin. Additional releases of solvent at the solvent storage tank were also documented during this period. Releases of large amounts of industrial solvent resulted in subsurface contamination present in an undissolved phase (NAPL) above and below the water table (Marine et al., 1984). This source DNAPL evaporates and dissolves, generating contaminated vapors/gas and a large dissolved plume. Presently, the dissolved phase and vadose zone are being addressed though a phased characterization/remediation program. Field activities specifically related to DNAPL characterization were initiated in 1991 (see Looney et al., 1992, Jackson et al., 1996, Jerome et al., 1998). Specific field activities related to the DNAPL remediation were initiated in FY97 with a demonstration of a remediation technology for destroying the DNAPL below the water table at a location of known DNAPL (Jerome et al., 1997).

FY99 DNAPL investigation activities centered around further identifying areas of pure phase DNAPL below the water table. Goals of this work were to further understand the subsurface contaminant distribution within the M-Area and to identify locations below the water table where aggressive DNAPL remediation technologies should be pursued. Areas examined in FY99 were beneath and adjacent to the M-Basin. Borings were completed using the roto-sonic drilling method and then grouted to surface. Two of the borings were drilled at an angle and one boring was drilled on the vertical. Core was collected continuously from surface to total depth for all borings. Total depth was to the top of the Green Clay confining unit (approximately $200 \mathrm{ft}$ msl, depth of $155 \mathrm{ft}$ ). 


\section{Selection of Drilling Locations}

Based on available information, residual DNAPL above the water table is within fine grained (silt and clay) layers. Residual DNAPL below the water table will migrate toward, and collect in, structural lows on top of fine grained layers. Gravitational movement of the DNAPL below the water table results in thin (but laterally extensive) layers of contaminant migration toward the accumulation areas. Locations selected below and adjacent to the M-Basin were to further investigate movement of DNAPL from beneath the basin, one of the key sources of solvent contamination within the A/M-Area.

Figure 1 identifies the resulting borings by location. Each location is identified and the basis for selection presented below. Drilling activities were centered adjacent to suspected sources of solvent discharge.

MRS26. This boring is located adjacent to the inlet of the M-Area Basin. This boring was drilled on a $45^{\circ}$ angle. This area is a known source of DNAPL as spent solvents were disposed into this basin via a subsurface process sewer line. Because the basin has an approved RCRA cap in place the only acceptable way to investigate below the inlet of the basin was to drill at an angle.

MRS27. This boring is located on the opposite side of the M-Area Basin from the inlet line. This boring was drilled on $4^{\circ}$ angle to the center of the basin. As with boring MRS26, the purpose of this boring is to evaluate the migration of the spent solvents as they seeped through the bottom of the unlined basin.

MRS28. This boring is located between the M-Basin and the area where an in situ oxidation demonstration (Borings and/or Wells MOX 1 through 11) was conducted in 1997 (Jerome et al., 1997). 


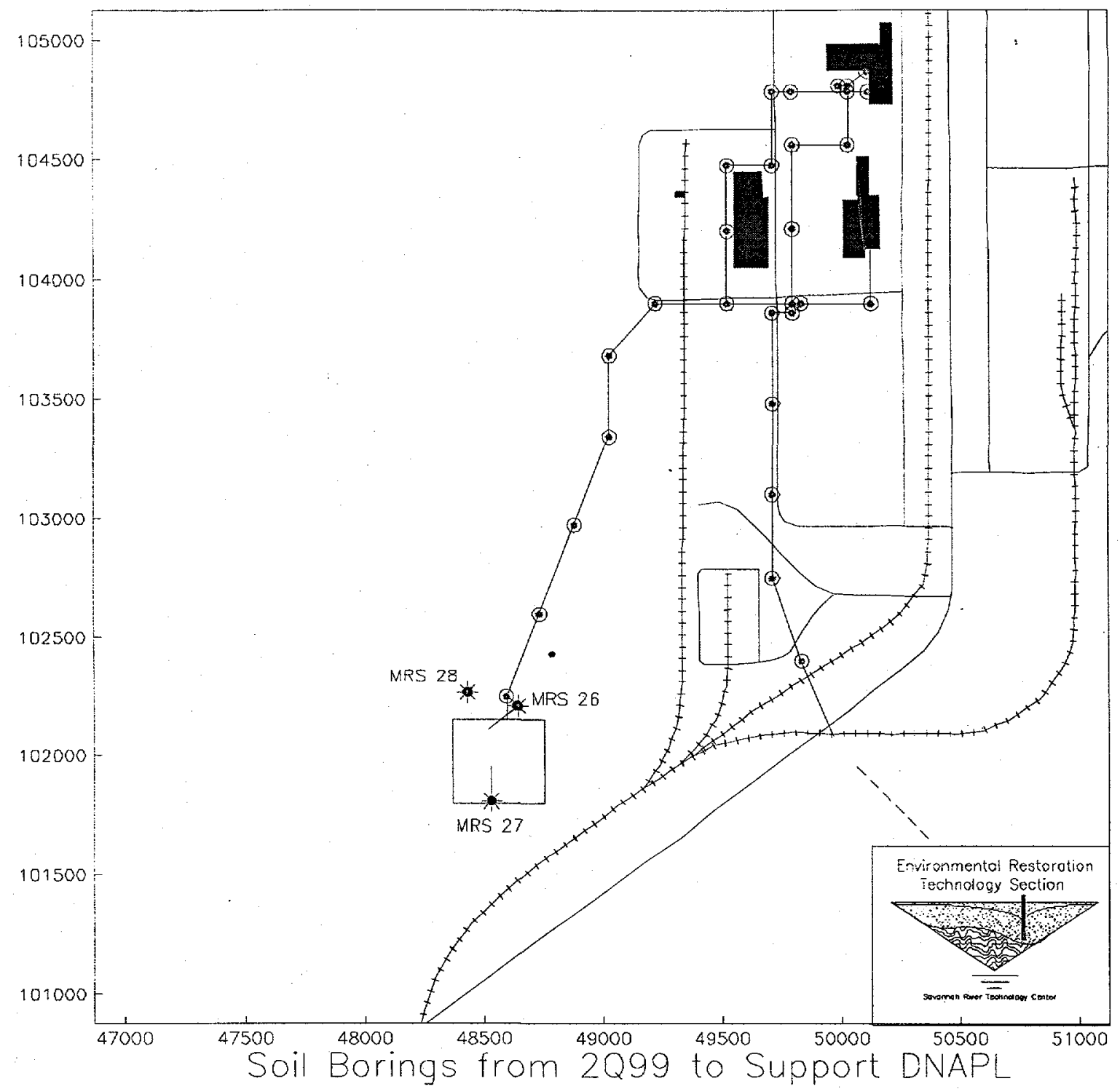

Characterization at the M-Area Basin.

Figure 1: Location Map of FY99 Borings to Support Investigation of DNAPL

Sources in the A/M Area 


\section{Field Activities}

The above identified three soil borings were drilled using the rotosonic drilling technology for purposes of DNAPL characterization at the M-Area Basin. Drilling activities occurred in April and May 1999. The holes were drilled to total depths of approximately $155 \mathrm{ft}$., equivalent to the top of the Green Clay confining unit. Two of the borings (MRS26 and MRS27) were drilled on an angle of $45^{\circ}$. Table 1 is a list of all borings, surface northing, surface easting, surface elevation, total depth, total depth northing, total depth easting, total depth elevation.

Table 1: Location Data for 2Q99 Borings to Support Investigation of DNAPL Sources at the M-Area Basin

\begin{tabular}{|l|c|c|c|c|c|c|c|}
\hline Boring ID & $\begin{array}{c}\text { Surface } \\
\text { Northing }\end{array}$ & $\begin{array}{c}\text { Surface } \\
\text { Easting }\end{array}$ & $\begin{array}{c}\text { Surface } \\
\text { Elevation } \\
\text { (ft msl) }\end{array}$ & $\begin{array}{c}\text { Total } \\
\text { Depth } \\
\text { (total } \\
\text { footage) }\end{array}$ & $\begin{array}{c}\text { Total } \\
\text { Depth } \\
\text { Northing }\end{array}$ & $\begin{array}{c}\text { Total } \\
\text { Depth } \\
\text { Easting }\end{array}$ & $\begin{array}{c}\text { Total } \\
\text { Depth } \\
\text { Elevation } \\
\text { (ft msl) }\end{array}$ \\
\hline MRS26* & 102210.7 & 48646.1 & 357.4 & $\begin{array}{c}157 \\
(224)\end{array}$ & 102109.4 & 48525.3 & 200 \\
\hline MRS27* & 101808.0 & 48534.4 & 351.2 & $\begin{array}{c}149 \\
(211)\end{array}$ & 101957.1 & 48534.4 & 202 \\
\hline MRS28 & 102268.4 & 48435.2 & 358.3 & $\begin{array}{c}157 \\
(157)\end{array}$ & 102268.4 & 48435.2 & 201.3 \\
\hline
\end{tabular}

NOTE: * Indicates borings drilled on an angle.

Soil plug samples were collected from surface to total depth for each location and analyzed for TCE and PCE concentrations using a static (equilibrium) headspace method (Looney et al., 1993, EPA, 1995). Sampling intervals for each hole were determined based on distance from a source (e.g. M-Area Basin) and modified in the field based on field measurements with a photo-ionization detector (PID). Samples were collected at MRS 26 on 1 to 2 foot intervals along the length of the boring. This boring was positioned at the inlet to the basin, and PID measurements indicated volatile organic contaminants (VOCs) along its length. Samples were collected at MRS27 and MRS28 on 5 foot intervals to 114 and 121 foot depths, respectively, and then at 1 to 2 foot intervals to total depth. 
Sediment samples were collected by taking a $2 \mathrm{cc}$ plug sample from the center of the core using a modified plastic syringe. The plug was transferred to a $22 \mathrm{ml}$ vial containing 5 $\mathrm{ml}$ of nano-pure water and the vial was sealed with a crimped septum top for later head space analysis. Duplicate samples were collected at each depth and all samples were stored at $4^{\circ} \mathrm{C}$ until analysis. Twenty percent $(20 \%)$ of the duplicate samples were analyzed as a quality control check.

Each sample was weighed and then analyzed on a HP 5890 Series gas chromatograph (GC) equipped with flame ionization detector (FID) and electron capture detector (ECD). Equilibrated headspace gas was sub-sampled and transferred to the GC using an automated head space sampler. Equivalent water concentrations were calculated using the appropriate detector (ECD for low concentrations, FID for high concentrations). Mass soil concentrations ( $\mathrm{ppb}, \mu \mathrm{g} / \mathrm{kg}$ ) were calculated based on an equal head space volume from $7.5 \mathrm{ml}$ of water standards and approximately $7.5 \mathrm{ml}$ of water/soil matrix and were corrected for the mass difference between soil and water. The gas chromatograph was calibrated using certified solvent mixtures in methanol diluted to specific concentrations. Standard concentrations used were 3, 5, 10, 50, 250, 500, and $1000 \mathrm{ppb}$ $(\mu \mathrm{g} / \mathrm{l})$. The standards were analyzed for vinyl chloride, freon-11, freon-113, 1,1-DCE, trans-DCE, cis-DCE, 1,1,1-TCA, $\mathrm{CCl}_{4}$, TCE, and PCE.

\section{Results of Subsurface Investigations}

Figures 2 through 4 are depth concentration profiles of TCE and PCE for each boring and the associated lithologic logs. Figure 5 provides the legend for Figures 2 through 4 and those presented in Appendix A. The bulk soil concentrations ( $\mathrm{x}$-axis of each figure) are graphed on different scales due to the wide range of concentrations between borings. Appendix A contains the same depth concentration profiles with field core descriptions incorporated on an expanded scale to allow a more detailed presentation. Also contained in Appendix A are depth/concentration tables for the three cores drilled. 
A/M Area data collected from the early 1980 's through the present supports a conceptual model that DNAPL is migrating from the M-Basin towards monitoring well MSB76 (westward) below the water table along the Green Clay confining unit or along an intermediate clay located above the Green Clay confining unit. There has been little evidence for migration to the east or north. The data collected from MRS 26, 27 and 28 characterization borings substantiates this hypothesis. Data collected from boring MRS 27 , drilled on the eastern side of the basin angling toward the basin center, did not indicate the presence of DNAPL. The highest concentrations recorded in boring MRS 27 were $0.032 \mu \mathrm{g} / \mathrm{g}$ of TCE and $0.017 \mu \mathrm{g} / \mathrm{g}$ of PCE, at elevations of $204 \mathrm{ft} \mathrm{msl}$ and $229 \mathrm{ft}$ msl, respectively. Data collected from boring MRS 26, drilled on the northern side of the basin angling beneath the basin's inlet pipe, indicated the presence of DNAPL. The highest concentrations recorded in boring MRS 26 were $22.1 \mu \mathrm{g} / \mathrm{g}$ of TCE and 198.3 $\mu \mathrm{g} / \mathrm{g}$ of PCE, at elevations of $262 \mathrm{ft} \mathrm{msl}$ and $240 \mathrm{ft} \mathrm{msl}$, respectively. Boring MRS 28 , located on the western side of the basin indicated concentrations as high as $1.917 \mu \mathrm{g} / \mathrm{g}$ TCE and $12.040 \mu \mathrm{g} / \mathrm{g}$ PCE at elevations of $208 \mathrm{ft} \mathrm{msl}$ and $227 \mathrm{ft} \mathrm{msl}$, respectively. 
WSRC-TR-99-00468

August 1999

Revision 0

Figure 2. Depth Concentration Profile for Boring MRS 26, drilled at a $45^{\circ}$ angle beneath inlet to M-Area Basin.

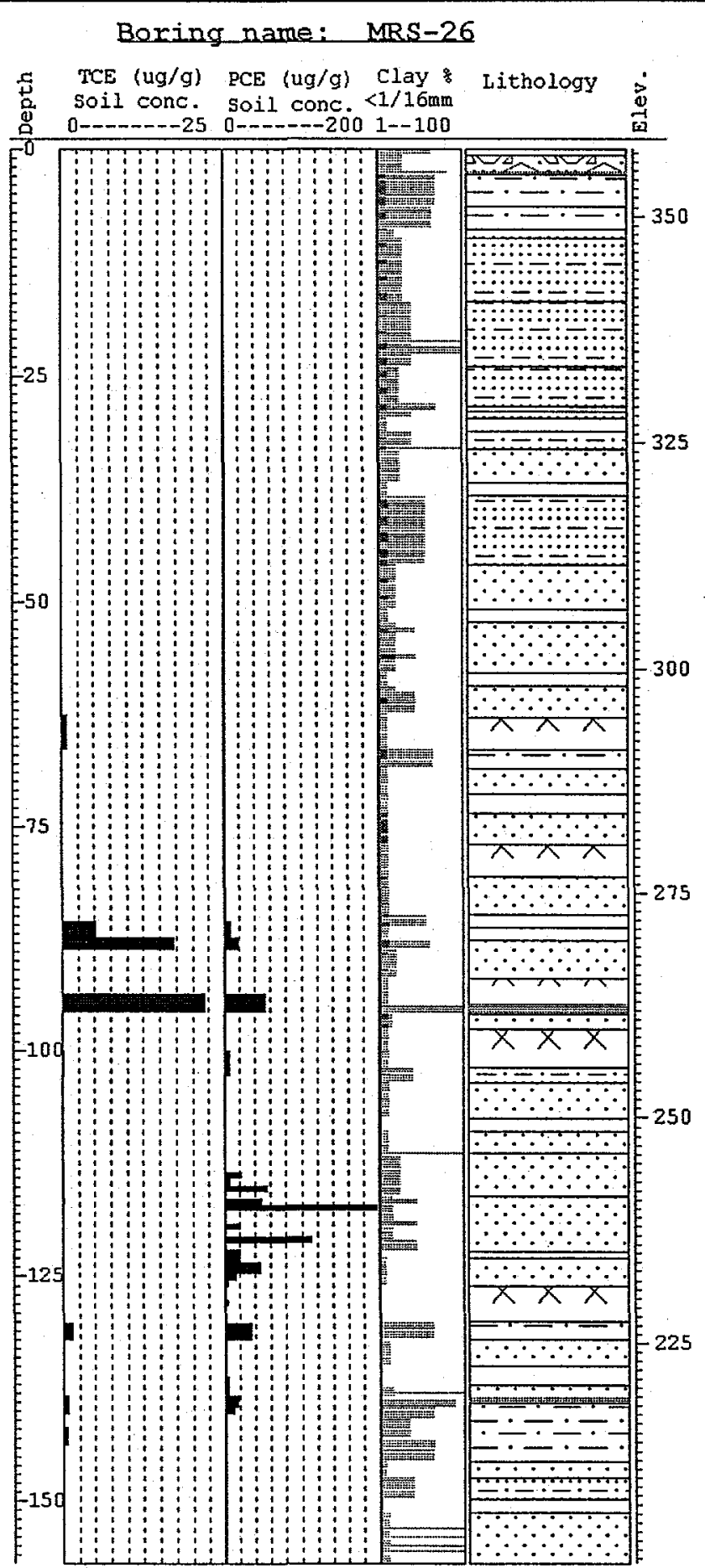


Figure 3. Depth Concentration Profile for Boring MRS 27, drilled at a $45^{\circ}$ angle from southern side of M-Area Basin to center of basin.

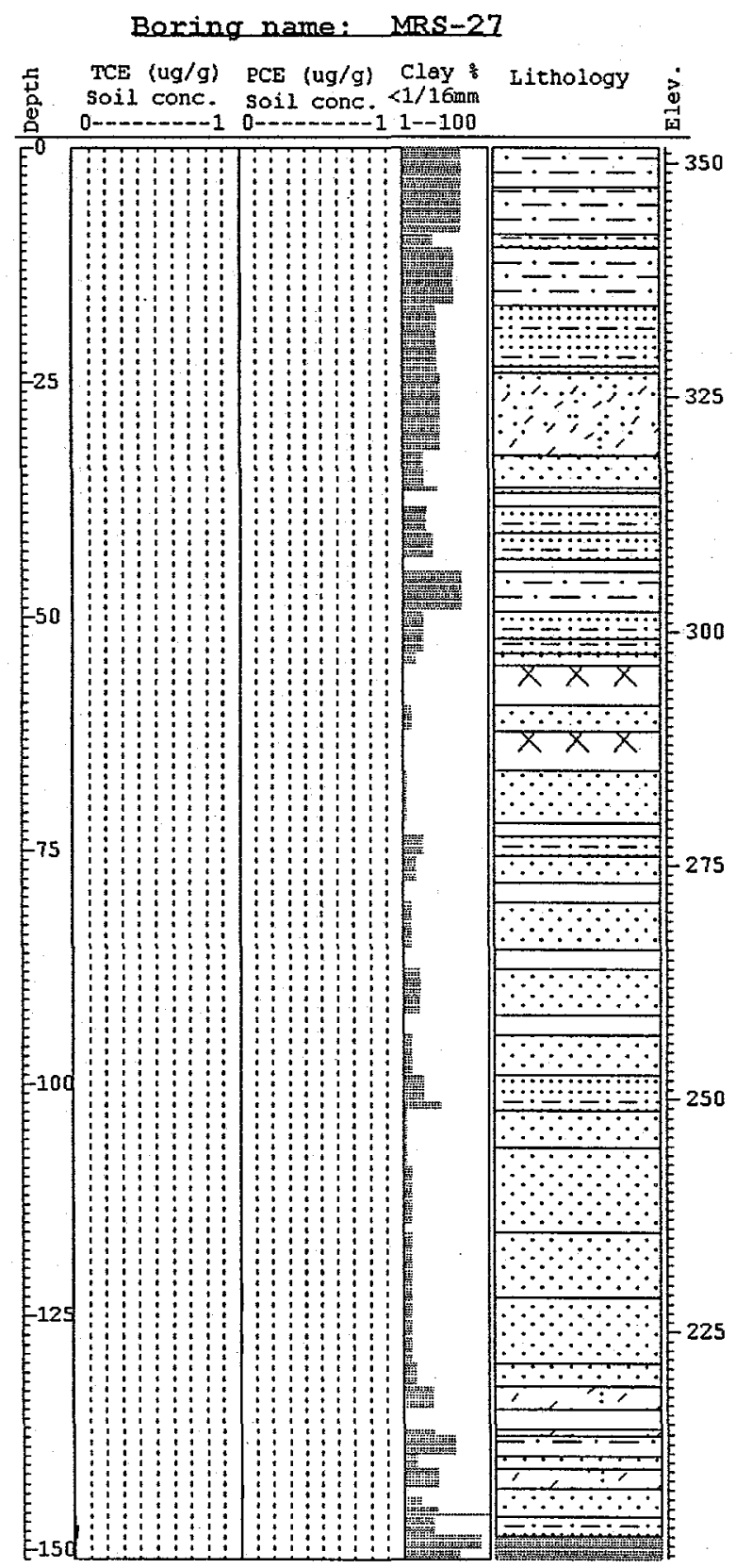


Figure 4. Depth Concentration Profile for Boring MRS 28, vertical boring adjacent to northern side of M-Area Basin

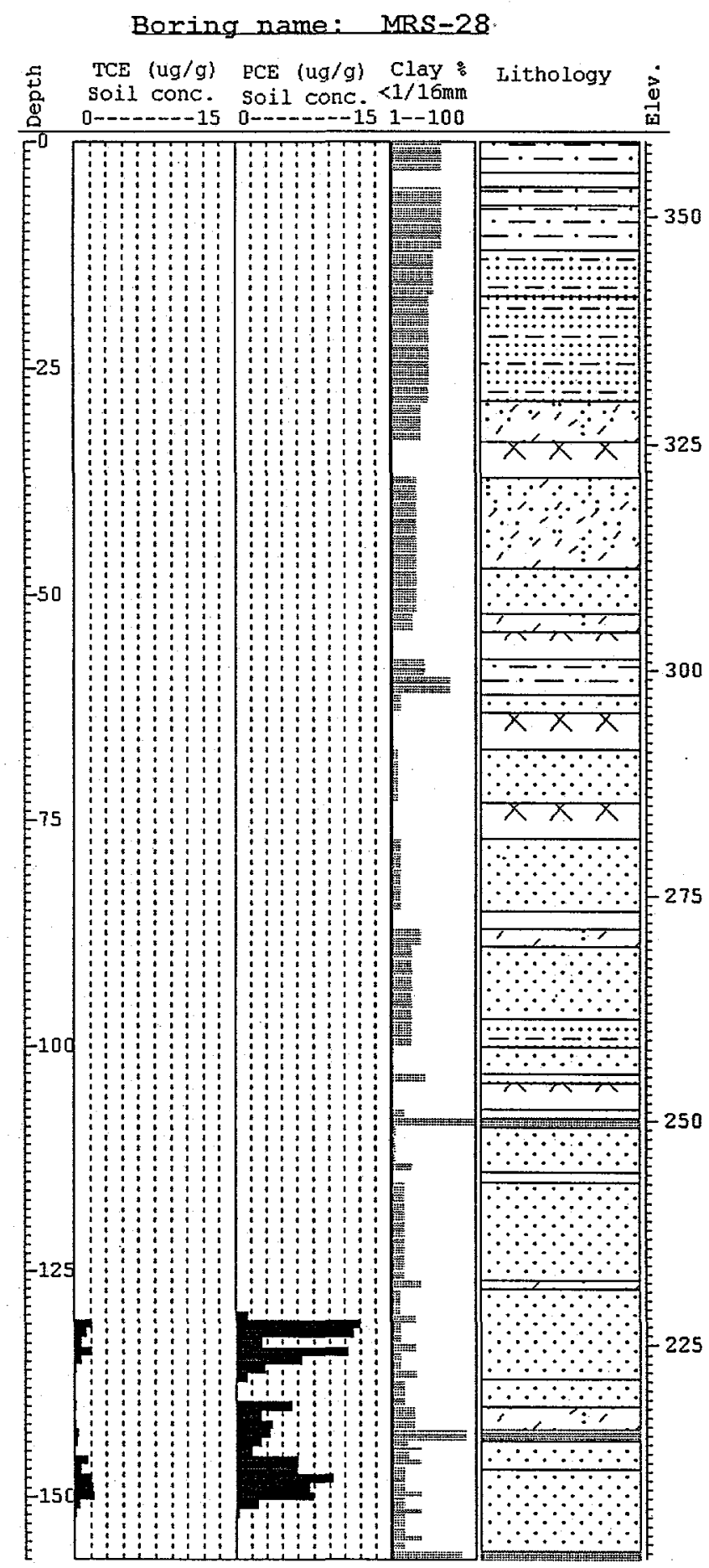


Figure 5. Lithology Key for Depth Concentration Profiles and Lithology Profiles
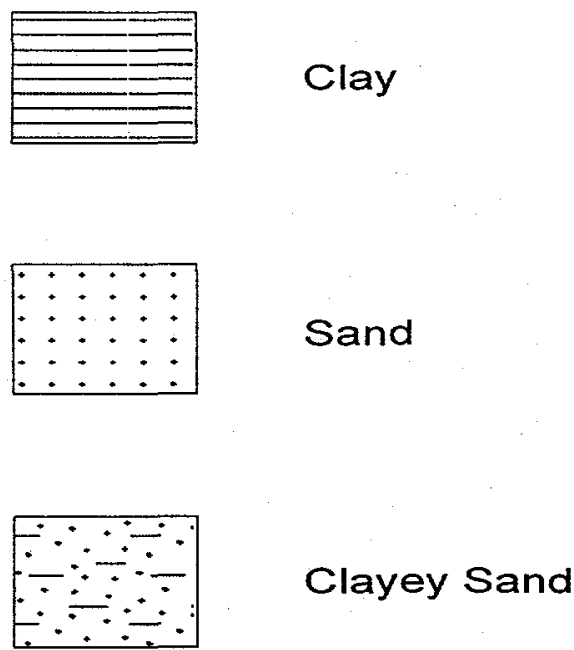

\begin{tabular}{rr}
$\square \div \because$ \\
\hdashline$\cdots$
\end{tabular}

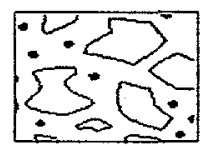

Gravel

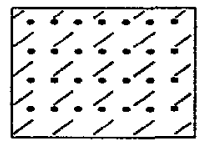

Silty Sand

$x \times x$
$x \times x$
$x \times x$

No Recovery 


\section{Evaluation of Results}

Evaluation of this data in relation to the simple estimate of DNAPL concentrations, indicate DNAPL below the inlet of the basin is primarily in the form of PCE. Looking at the vertical distribution of the contaminants in this boring indicates the contaminants are located in a zone ranging from elevations of $242 \mathrm{ft} \mathrm{msl} \mathrm{downward} \mathrm{to} 233 \mathrm{ft} \mathrm{msl}$. This is a region of sandy material overlaying a sandy clay zone of approximately $3 \mathrm{ft}$ thickness at a top elevation of $228 \mathrm{ft} \mathrm{msl}$. This contaminated zone appears to be within a smear zone created from natural fluctuations in the water table. The water table at the basin is estimated to range from $119 \mathrm{ft}$ depth to $125 \mathrm{ft}$ depth ( $238 \mathrm{ft} \mathrm{msl}$ to $232 \mathrm{ft} \mathrm{msl}$ ). Table 2 identifies the elevations at which DNAPL and suspect DNAPL concentrations were reported for the three borings drilled this year.

Boring MRS 28 data suggest that contaminants are moving through the area which is located between the M-Area Basin and monitoring well MSB 76. Concentrations of TCE and PCE were reported in boring MRS 28. However, none of the concentrations were above the $45 \mu \mathrm{g} / \mathrm{g}$ calculated as a rule of thumb number for indication of DNAPL in the immediate area. This indicates that boring MRS 28 was drilled within an area of the dissolved plume, but not within the narrower area of the DNAPL transport zone.

Data from boring MRS 27 suggests DNAPL is not moving eastward from the basin. As this is the only boring available on the eastern side of the basin, an additional one or two borings along this edge of the basin is warranted to confirm or deny the findings of boring MRS 27. 
Table 2. Identification of Elevations at which DNAPL and suspect DNAPL

concentrations were reported for borings from the FY99 DNAPL investigations at the MArea Basin.

\begin{tabular}{|c|c|c|c|}
\hline Elevation & MRS26 & MRS27 & MRS28 \\
\hline \multicolumn{4}{|l|}{263} \\
\hline 262 & D & & \\
\hline \multicolumn{4}{|l|}{261} \\
\hline \multicolumn{4}{|l|}{260} \\
\hline \multicolumn{4}{|l|}{259} \\
\hline \multicolumn{4}{|l|}{258} \\
\hline \multicolumn{4}{|l|}{257} \\
\hline \multicolumn{4}{|l|}{256} \\
\hline \multicolumn{4}{|l|}{255} \\
\hline \multicolumn{4}{|l|}{254} \\
\hline \multicolumn{4}{|l|}{253} \\
\hline \multicolumn{4}{|l|}{252} \\
\hline \multicolumn{4}{|l|}{251} \\
\hline \multicolumn{4}{|l|}{$\frac{250}{240}$} \\
\hline \\
\hline \multicolumn{4}{|l|}{248} \\
\hline \multicolumn{4}{|l|}{247} \\
\hline \multicolumn{4}{|l|}{246} \\
\hline \multicolumn{4}{|l|}{245} \\
\hline 244 & SD & & nd \\
\hline 243 & & & 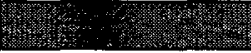 \\
\hline 242 & $\mathrm{D}$ & & nd \\
\hline 241 & $\mathrm{D}$ & & nd \\
\hline 240 ( water table $)$ & $\bar{D}$ & & nd \\
\hline \multicolumn{4}{|l|}{239} \\
\hline \multicolumn{4}{|l|}{238} \\
\hline \multicolumn{4}{|l|}{237} \\
\hline \multicolumn{4}{|l|}{236} \\
\hline \multicolumn{4}{|l|}{235} \\
\hline \multicolumn{4}{|l|}{234} \\
\hline \multicolumn{4}{|l|}{233} \\
\hline \multicolumn{4}{|l|}{232} \\
\hline \multicolumn{4}{|l|}{231} \\
\hline 230 & & & \\
\hline 229 & & & \\
\hline 228 & & & \\
\hline 227 & & & \\
\hline 226 & SD & & \\
\hline 225 & & & \\
\hline
\end{tabular}




\begin{tabular}{|l|l|l|l|}
\hline Elevation & MRS26 & MRS27 & \multicolumn{1}{c|}{ MRS28 } \\
\hline 224 & & & \\
\hline 223 & & & \\
\hline 222 & & & \\
\hline 221 & & & \\
\hline 220 & & & \\
\hline 219 & & & \\
\hline 218 & & & \\
\hline 217 & & & \\
\hline 216 & & & \\
\hline 215 & & & \\
\hline 214 & & & \\
\hline 213 & & & \\
\hline 212 & & & \\
\hline 211 & & & \\
\hline 210 & & & \\
\hline 209 & & & \\
\hline 208 & & & \\
\hline 206 & & & \\
\hline 205 & & & \\
\hline 204 & & & \\
\hline 203 & & & \\
\hline 201 & & & \\
\hline 200 & & & \\
\hline
\end{tabular}

D - DNAPL concentrations (45 $\mu \mathrm{g} / \mathrm{g}$ PCE or greater), SD - suspect DNAPL concentrations (between $1 / 2$ the DNAPL concentration and the DNAPL concentration, $22.5 \mu \mathrm{g} / \mathrm{g}<\mathrm{x}<45 \mu \mathrm{g} / \mathrm{g}$ ). nd - below detection limit of $0.001 \mu \mathrm{g} / \mathrm{g}$. Clear blocks indicate concentrations between suspect DNAPL and below detection. Shaded blocks indicate no samples collected at those elevations.

\section{Future Work}

The data presented in this report and in the FY98 report should be incorporated with the data collected near the M-Area Basin within the last 20 years. This data could be evaluated using three dimensional visualization techniques to determine if sufficient information is available to accurately delineate the DNAPL migration pathway from the M-Area Basin. This would include consolidating the recently completed mapping of the 
structure and distribution of mud within the Steed Pond Aquifer and Vadose Zone beneath A/M Area (Parker, et al., June 1999) and concentration data from soil plug samples beneath and adjacent to the M-Area Basin.

Upon completion of this evaluation, data gaps should be filled to improve the delineation of the DNAPL migration pathway.

\section{References}

EPA, 1995. Method 5021: Volatile Organic Compounds in Soils and Other Solid Matrices Using Equilibrium Headspace Analysis. Environmental Protection Agency, Washington DC.

Gordon, D.E., 1982. Preliminary Technical Summary M-Area Groundwater Cleanup Facility. DPST-82-0069. E.I. duPont de Nemours \& Co., Savannah River.Laboratory, Aiken, SC 29808.

Jackson, D. J. Jr., T. H. Payne, B. B. Looney and J. Rossabi, 1996. Estimating the Extent and Thickness of DNAPL within the A/M Area of the Savannah River Site. WSRC-RP96-0574. Westinghouse Savannah River Company, Aiken, SC 29808.

Jerome, K. M., B. Riha, B. B. Looney, 1997. Final Report for Demonstration of In Situ Oxidation of DNAPL Using the Geo-Cleanse Technology. WSRC-TR-97-00283, Westinghouse Savannah River Company, Aiken, SC 29808.

Jerome, K. M., J. V. Noonkester, B. B. Looney, J. L. Simmons, S. L. Baxley, 1998. A/M Area DNAPL Characterization Report For Cores Collected in FY97 and 1Q98 and 2Q98. WSRC-TR-98-00296. Westinghouse Savannah River Company, Aiken, SC 29808.

Looney, B. B., J. Rossabi, D. M. Tuck, J. E. Jordan, C. L. Bergren, R. VanPelt, J. Kirr, W. E. Jones, A. E. Stevenson, B. S. Kristianson, B. K. Morgan, R. C. Smalley, M. K. 
Stewart, 1992. Assessing DNAPL Contamination, A/M Area, SRS, Phase I Results.

WSRC-RP-92-1302. Westinghouse Savannah River Company, Aiken, SC 29808.

Looney, B. B., C. A. Eddy, W. R. Sims, 1993. Evaluation of Headspace Method for Volatile Constituents in Soils and Sediments. In Measuring and Interpreting VOCs in Soils: State of the Art and Research Needs., U. S. Environmental Protection Agency, Env. Monitoring Systems Laboratory, Las Vegas, NV 89193.

Marine, I.W. and H.W. Bledsoe, 1984. Supplemental Technical Summary M-Area Groundwater Investigation. DPSTR-84-112. E. I. duPont de Nemours \& Co., Savannah River Laboratory, Aiken, SC 29808.

Parker, W. H., A. D. Smits, M. K. Harris, D. G. Jackson, Jr., and K. L. Hawkins, 1999. Baseline Mapping Study of the Steed Pond Aquifer and Vadose Zone Beneath A/M Area, Savannah River Site (U). WSRC-TR-99-00295. Westinghouse Savannah River Company, Aiken, SC 29808. 


\section{Appendix A. Depth Concentration Information}

Expanded Depth Concentration Profiles for Borings MRS 26, 27 and 28.

Depth Concentration Tables for Borings MRS 26, 27, and 28. 


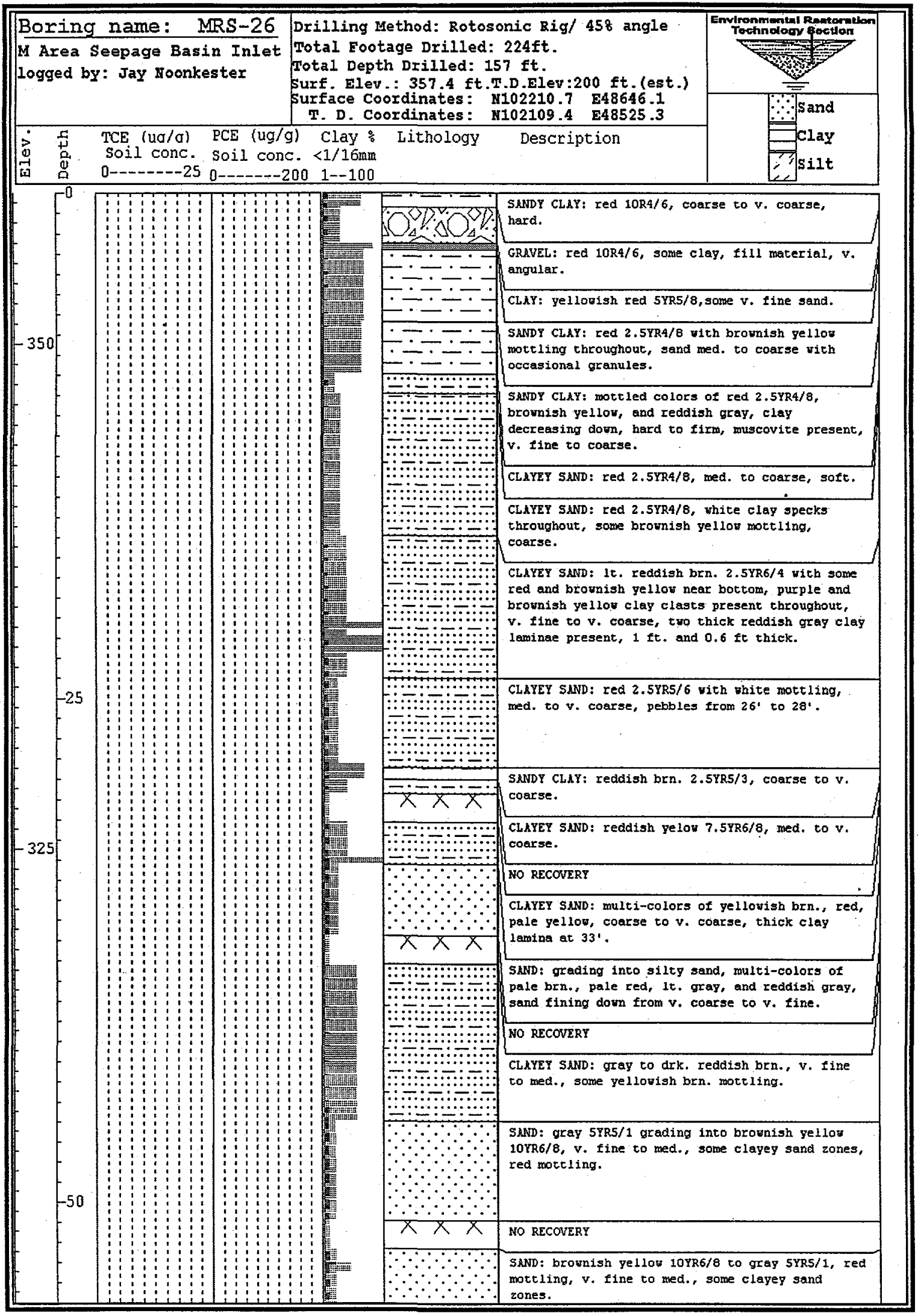


Revision 0

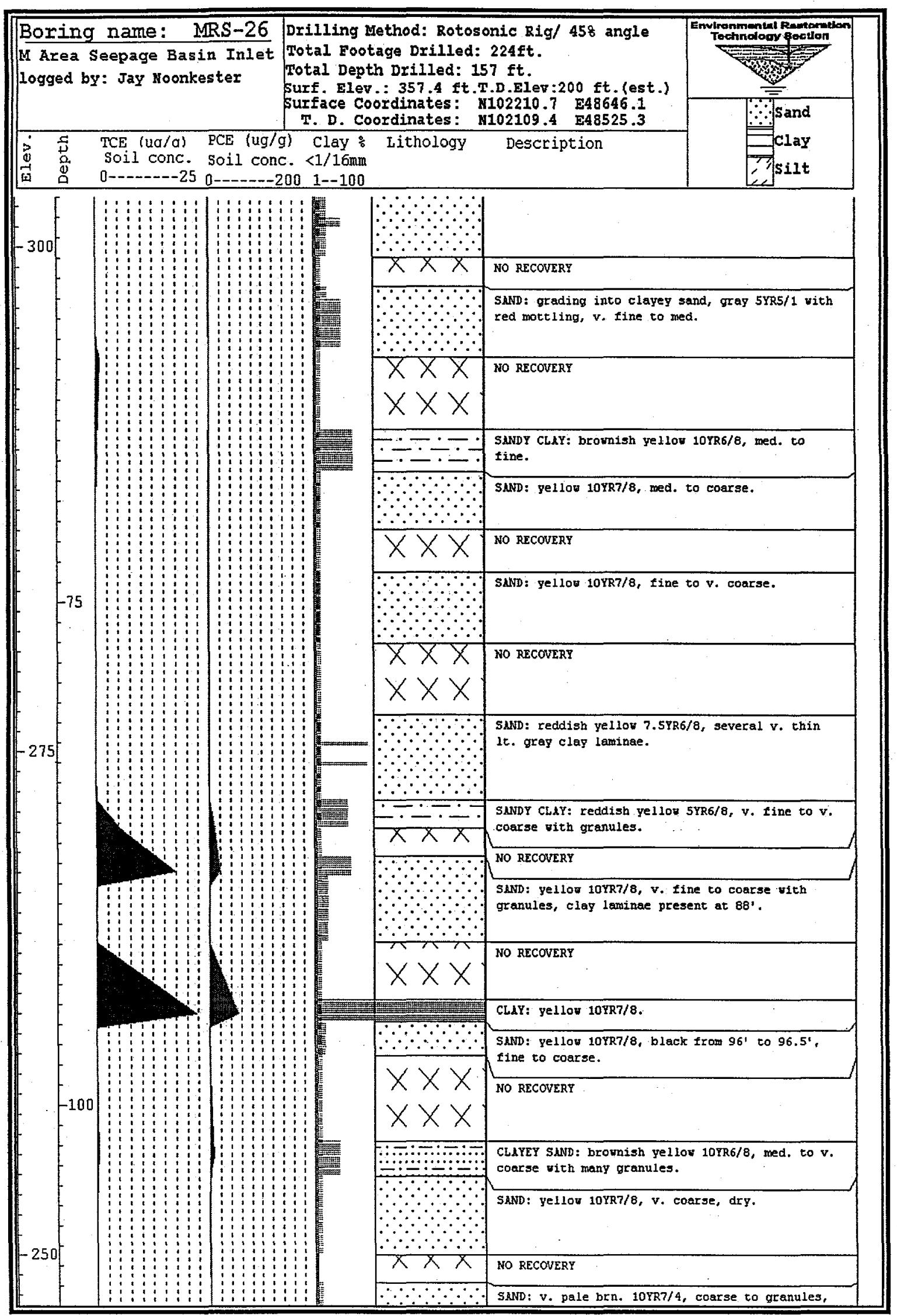




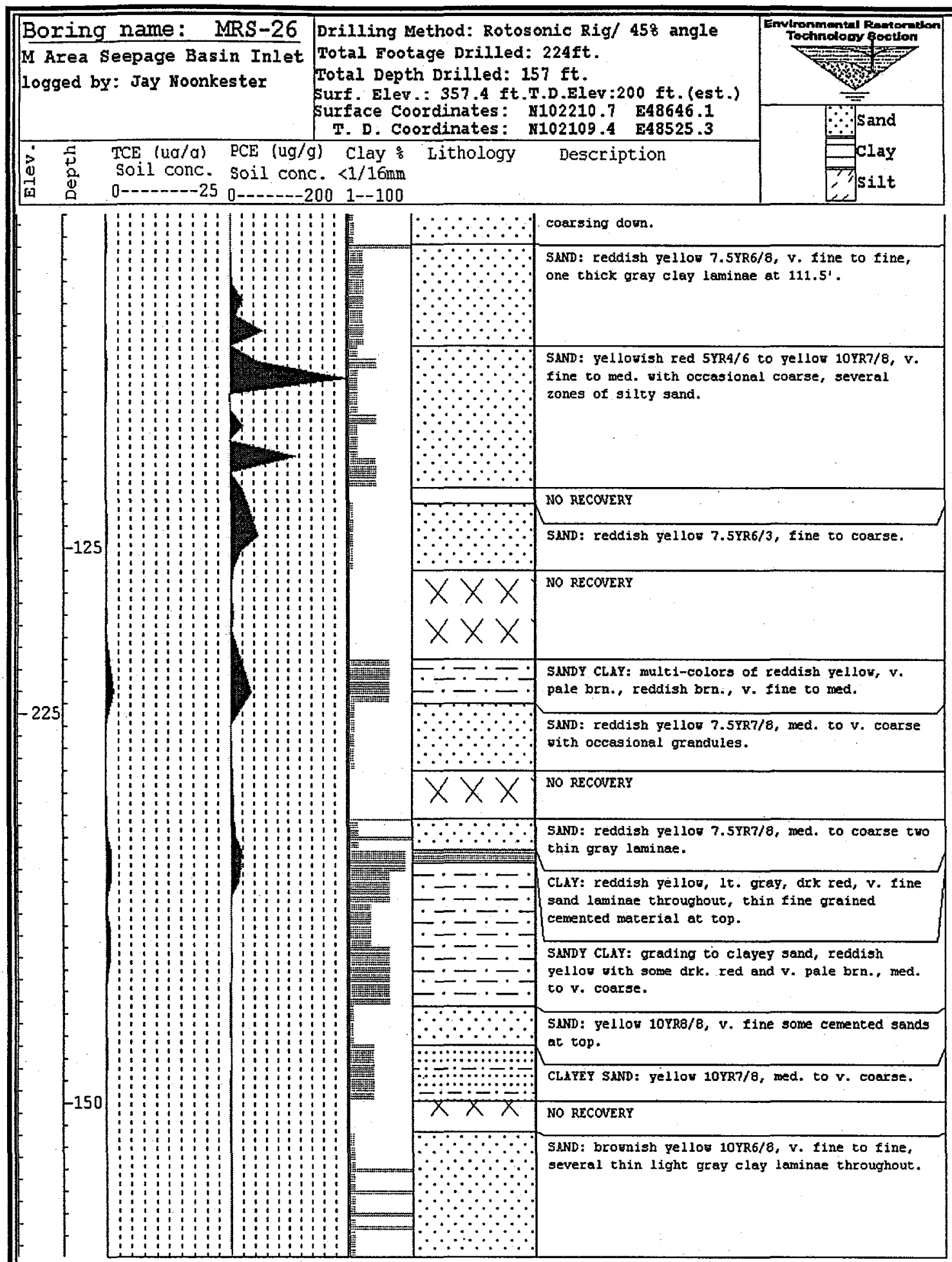


Revision 0






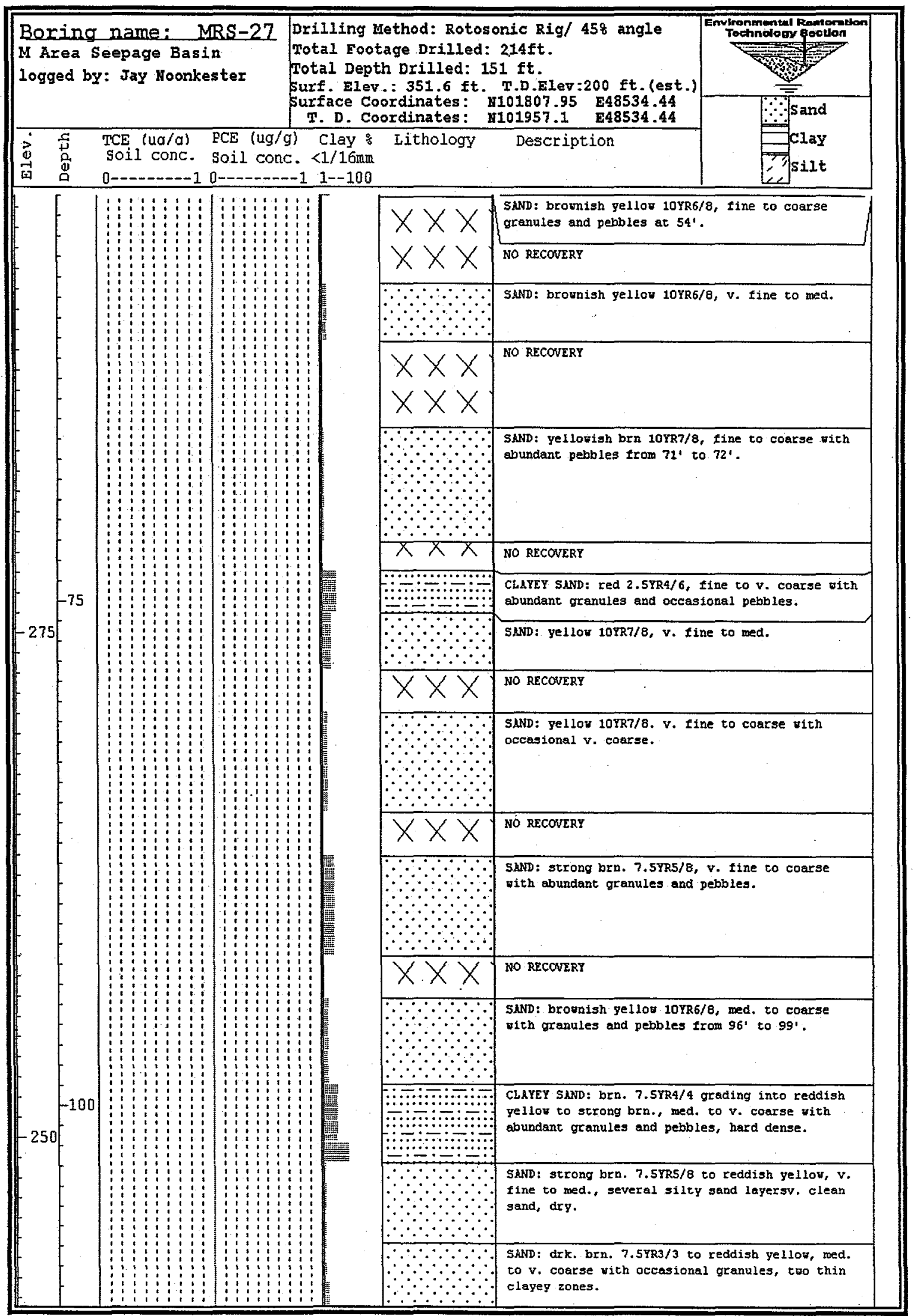


Revision 0

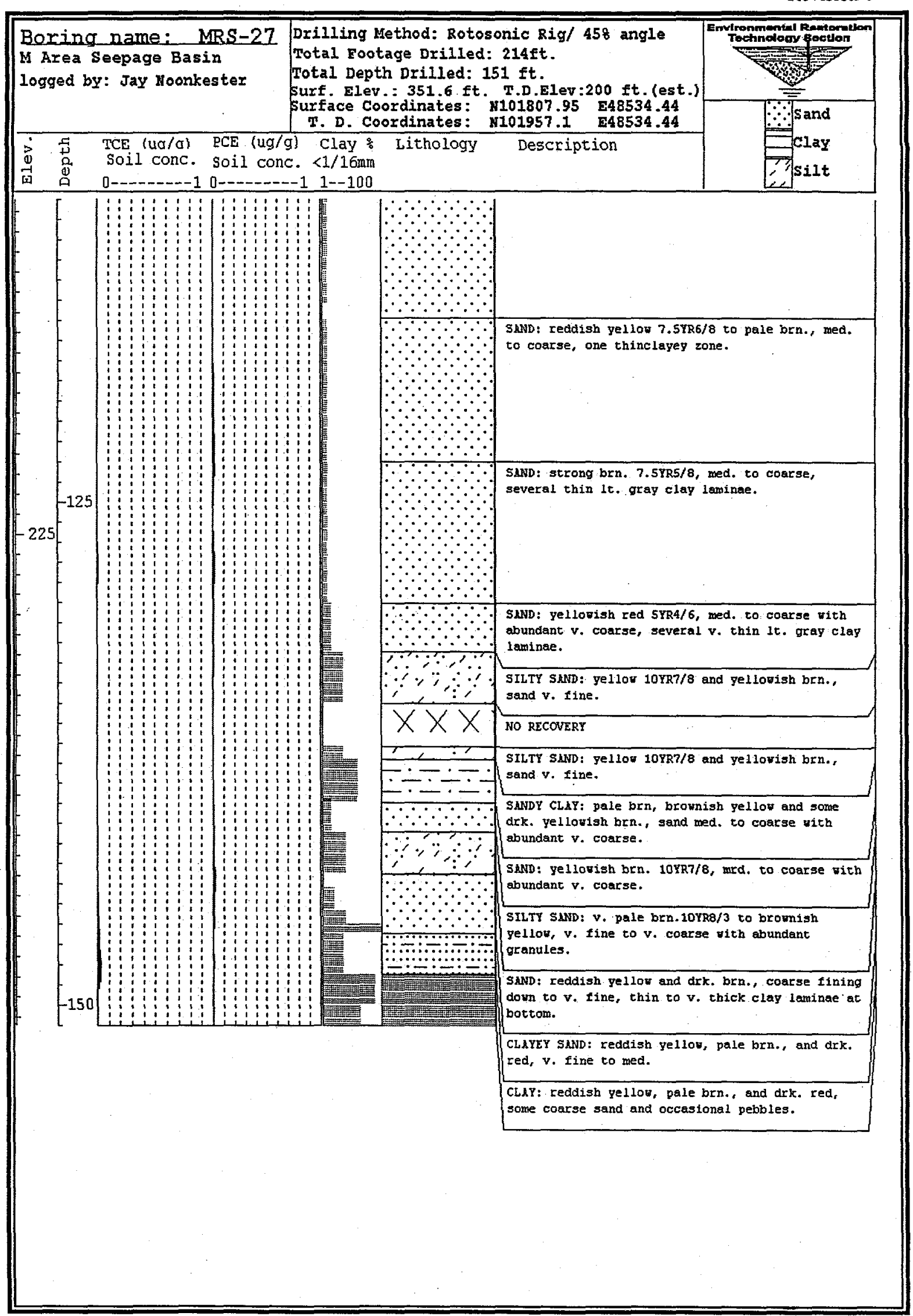




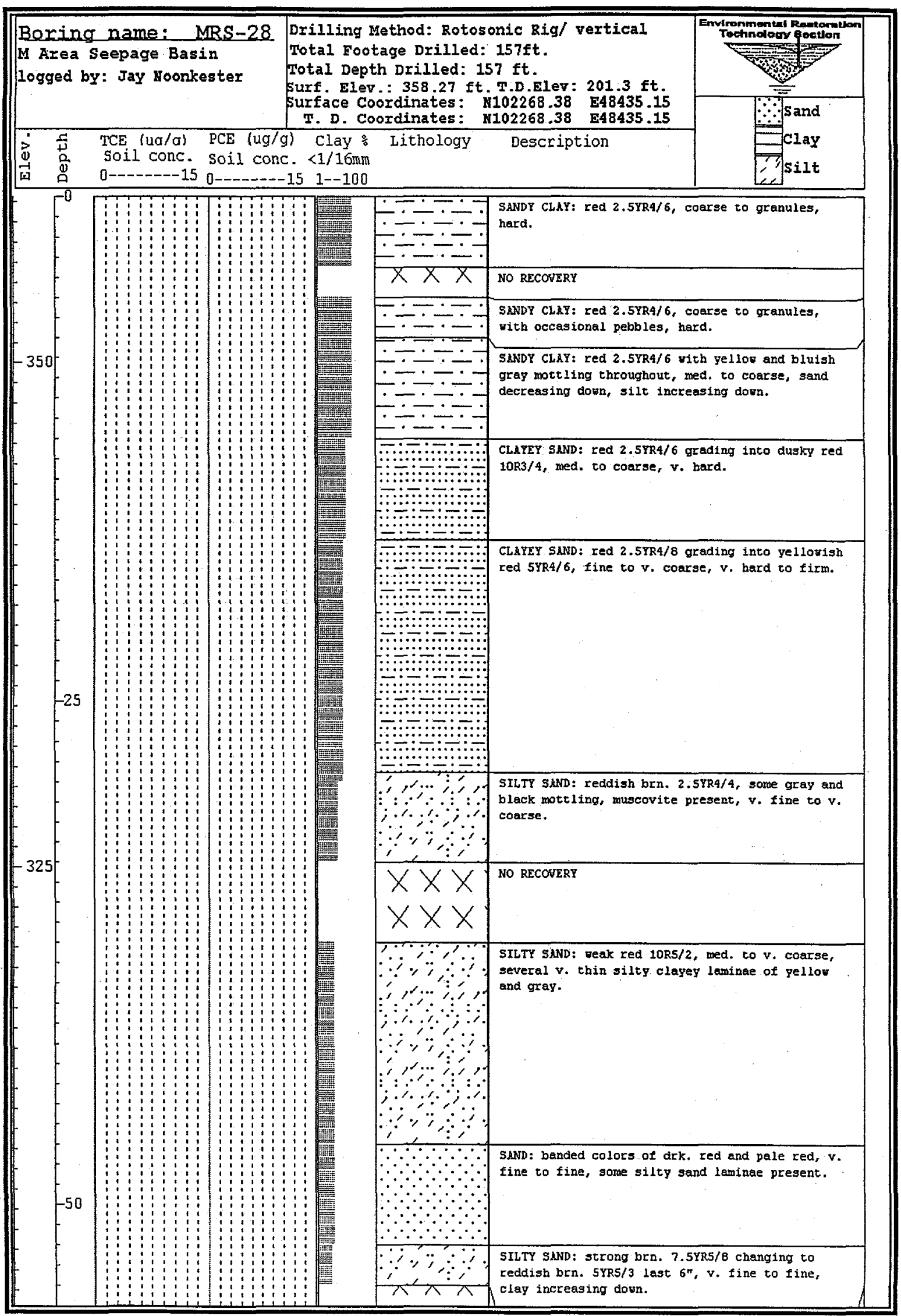


WSRC-TR-99-00468

August 1999

Revision 0

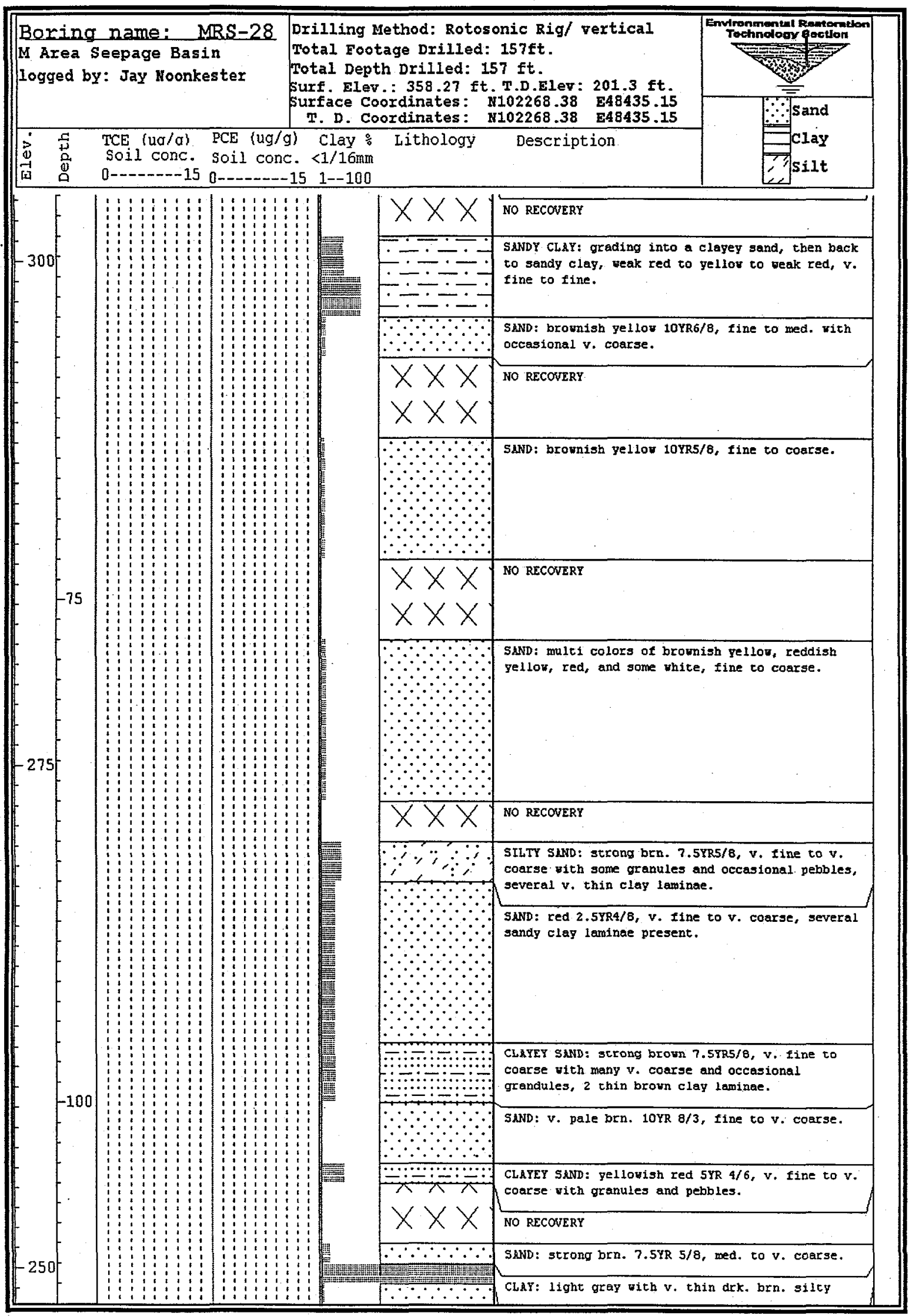


Revision 0

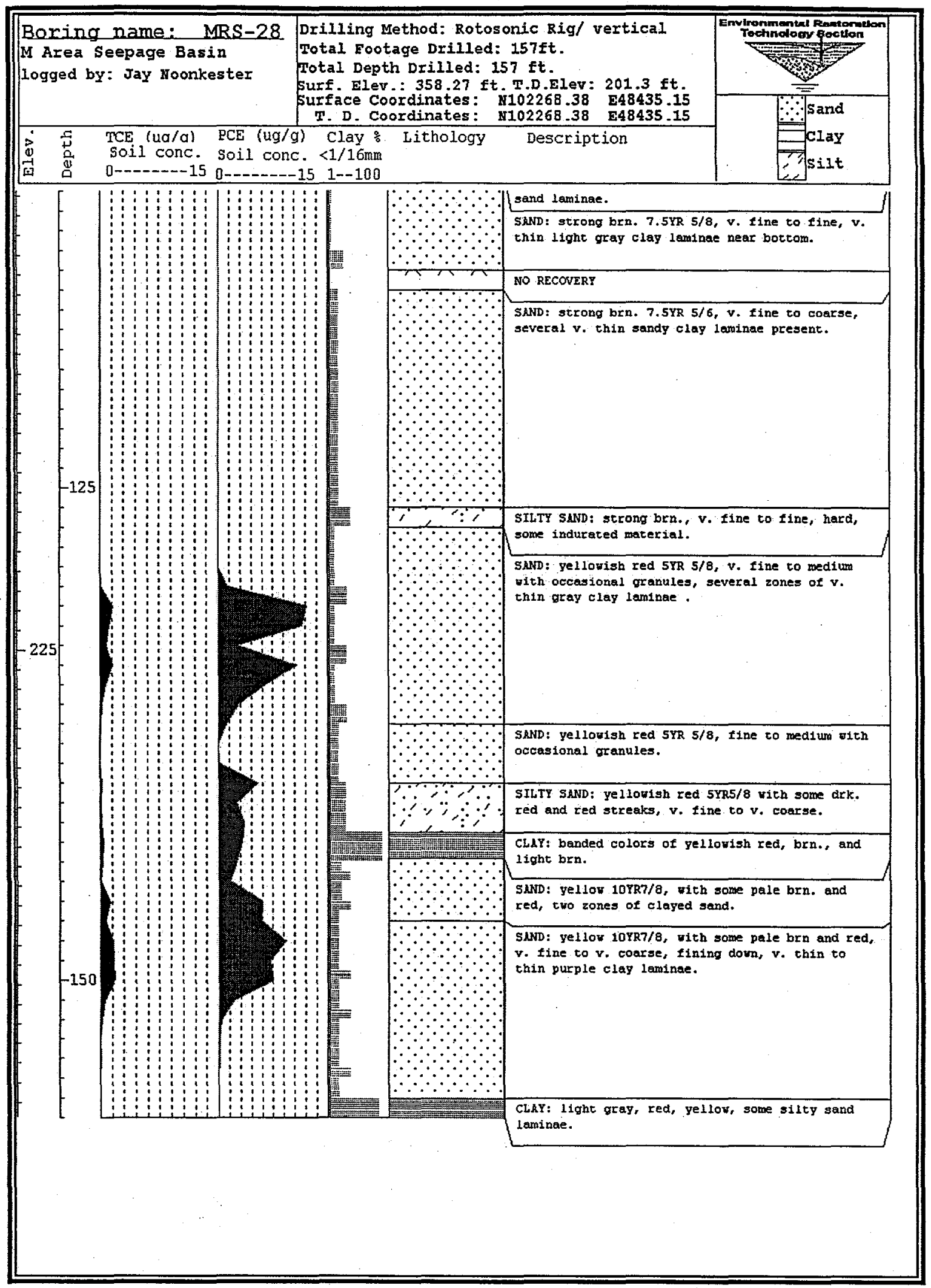


Table A-1. Depth Concentration Profile for Soil Boring MRS26. Drilled at a $45^{\circ}$ angle from the north side of the M-Area Basin to below the inlet.

\begin{tabular}{|c|c|c|c|c|c|c|c|}
\hline \multirow[b]{2}{*}{ ID } & \multirow{2}{*}{\begin{tabular}{|c|} 
Northing \\
Surface: \\
102210.73
\end{tabular}} & \multirow{2}{*}{$\begin{array}{l}\text { Easting } \\
\text { Surface: } \\
48646.11\end{array}$} & \multirow{2}{*}{$\begin{array}{l}\text { Elevation } \\
\text { (ft msl) }\end{array}$} & \multicolumn{4}{|c|}{ Soil Conc. (avg) } \\
\hline & & & & $\begin{array}{c}\text { TCE } \\
\text { (ug/g) }\end{array}$ & $\begin{array}{c}\text { PCE } \\
\text { (ug/g) }\end{array}$ & $\begin{array}{c}\text { TCA } \\
\text { (ug/g) }\end{array}$ & $\begin{array}{c}\mathrm{CCl} 4 \\
\text { (ug/g) }\end{array}$ \\
\hline \begin{tabular}{l|l} 
MRS26 & 01
\end{tabular} & 102206.6 & 48641.2 & 351 & $<0.001$ & 0.005 & $<0.001$ & $<0.001$ \\
\hline \begin{tabular}{l|l} 
RS26 & 02
\end{tabular} & 102204.4 & 48638.5 & 348 & $<0.001$ & $<0.001$ & $<0.001$ & 0.0 \\
\hline \begin{tabular}{l|l} 
MRS26 & 03
\end{tabular} & 102202.5 & 48636.4 & 345 & $<0.001$ & 0.001 & $<0.001$ & 0.00 \\
\hline \begin{tabular}{l|l} 
IRS26 & 04
\end{tabular} & 102199.8 & 48633.1 & 340 & $<0.001$ & $<0.001$ & $<0.001$ & 0.0 \\
\hline \begin{tabular}{l|l} 
MRS26 & 05 \\
\end{tabular} & 102198.0 & 48630.9 & 338 & $<0.001$ & 0.002 & $<0.001$ & $<0.00$ \\
\hline \begin{tabular}{|l|l|} 
MRS26 & 06
\end{tabular} & 102195.3 & 48627.7 & 333 & $<0.001$ & 0.003 & $<0.001$ & 0.00 \\
\hline \begin{tabular}{l|l} 
MRS26 & 07 \\
\end{tabular} & 102193.5 & 48625.5 & 331 & $<0.001$ & 0.005 & $<0.001$ & $<0.00$ \\
\hline \begin{tabular}{|l|l|} 
MRS26 & 08 \\
\end{tabular} & 102191.6 & 48623.4 & 328 & $<0.001$ & 0.004 & $<0.001$ & $<0.00$ \\
\hline \begin{tabular}{|l|l|} 
MRS26 & 09 \\
\end{tabular} & 102189.8 & 48621.2 & 325 & $<0.001$ & 0.005 & $<0.001$ & $<0.00$ \\
\hline \begin{tabular}{|l|l} 
MRS26 & 10
\end{tabular} & 102188.9 & 48620.1 & 323 & $<0.001$ & $<0.001$ & $<0.001$ & $<0.00$ \\
\hline \begin{tabular}{|l|l|} 
MRS26 & 11 \\
\end{tabular} & 102188.0 & 48619.0 & 322 & $<0.001$ & $<0.001$ & $<0.001$ & $<0.00$ \\
\hline \begin{tabular}{|l|l|} 
MRS26 & 12 \\
\end{tabular} & 102187.1 & 486.17 .9 & 321 & 0.001 & 0.006 & $<0.001$ & $<0.00$ \\
\hline \begin{tabular}{|l|l} 
MRS26 & 13 \\
\end{tabular} & 102183.5 & 48613.6 & 315 & $<0.001$ & 0.027 & $<0.001$ & $<0.00$ \\
\hline \begin{tabular}{|l|l|} 
MRS26 & 14 \\
\end{tabular} & 1021 & 48611.4 & 312 & $<0.001$ & 0.235 & $<0.001$ & $<0.00$ \\
\hline \begin{tabular}{|l|l|} 
MRS26 & 15 \\
\end{tabular} & 102179.4 & 48608.7 & 309 & 0.001 & 0.009 & $<0.001$ & $<0.00$ \\
\hline \begin{tabular}{|l|l|} 
MRS26 & 16 \\
\end{tabular} & 102178.9 & 48608.2 & 308 & 0.003 & 0.020 & $<0.001$ & $<0.00$ \\
\hline \begin{tabular}{|l|l|} 
MRS26 & 17
\end{tabular} & 102178.0 & 48607.1 & 306 & 0.015 & 0.065 & 0.001 & $<0.00$ \\
\hline \begin{tabular}{|l|l} 
MRS26 & 18 \\
\end{tabular} & 1021 & 48604.4 & 303 & 0.022 & 0.068 & 0.002 & $<0.1$ \\
\hline \begin{tabular}{|l|l} 
MRS26 & 19 \\
\end{tabular} & 102174.8 & 48603.3 & 302 & 0.041 & 0.114 & 0.003 & $<0.00$ \\
\hline \begin{tabular}{|l|l} 
MRS26 & 20 \\
\end{tabular} & 1 & 48602.8 & 301 & 0.002 & 0.005 & $<0.001$ & $<0.00$ \\
\hline \begin{tabular}{|l|l|} 
MRS26 & 21 \\
\end{tabular} & 73.5 & 48601.7 & 299 & 0.035 & 0.050 & 0.001 & $<0.00$ \\
\hline \begin{tabular}{|l|l} 
MRS26 22 \\
\end{tabular} & 71.2 & 48599.0 & 296 & 0.063 & 0.066 & $<0.001$ & $<0.00$ \\
\hline \begin{tabular}{|l|l|} 
MRS26 & 23 \\
\end{tabular} & 102 & 48598.4 & 295 & 0.222 & 0.211 & 0.003 & $<0.00$ \\
\hline \begin{tabular}{|l|l|} 
MRS26 & 24 \\
\end{tabular} & 102170.3 & 48597.9 & 294 & 0.909 & 0.993 & 0.013 & $<0.00$ \\
\hline \begin{tabular}{|l|l|} 
MRS26 & 25 \\
\end{tabular} & 102165.7 & 48592.5 & 287 & 0.001 & 0.002 & $<0.001$ & $<0.00$ \\
\hline \begin{tabular}{|l|l} 
MRS26 & 26
\end{tabular} & 102164.8 & 48591.4 & 286 & 0.005 & 0.005 & $<0.001$ & $<0.00$ \\
\hline \begin{tabular}{|l|l|} 
MRS26 & 27 \\
\end{tabular} & 102161.2 & 48587.1 & 280 & $<0.001$ & $<0.001$ & $<0.001$ & $<0.0$ \\
\hline \begin{tabular}{|l|l} 
MRS26 & 28 \\
\end{tabular} & 58.0 & 48583.3 & 275 & $<0.001$ & $<0.001$ & $<0.001$ & $<0.00$ \\
\hline \begin{tabular}{|l|l|} 
MRS26 & 29 \\
\end{tabular} & 102157.1 & 48582.2 & 274 & 0.010 & 0.006 & $<0.001$ & $<0.00$ \\
\hline \begin{tabular}{|l|l} 
MRS26 & 30 \\
\end{tabular} & 102156.2 & 48581.1 & 273 & 0.160 & 1.369 & $<0.001$ & $<0.00$ \\
\hline \begin{tabular}{|l|l|} 
MRS26 & 31 \\
\end{tabular} & 102155.3 & 48580.0 & 271 & 5.241 & 10.566 & 0.006 & $<0.00$ \\
\hline \begin{tabular}{|l|l} 
MRS26 32 \\
\end{tabular} & 102153.9 & 48578.4 & 269 & 17.385 & 19.891 & 0.018 & 0.00 \\
\hline \begin{tabular}{|l|l} 
MRS26 33 \\
\end{tabular} & 102153.5 & 48577.9 & 268 & 0.212 & 0.179 & $<0.001$ & 0.00 \\
\hline \begin{tabular}{|l|l|} 
MRS26 & 34
\end{tabular} & 102153.0 & 48577.3 & 268 & 0.226 & 0.180 & $<0.001$ & $<0.00$ \\
\hline \begin{tabular}{|l|l|} 
MRS26 & 35
\end{tabular} & 102152.6 & 48576.8 & 267 & 0.069 & 0.040 & $<0.001$ & $<0.00$ \\
\hline
\end{tabular}


WSRC-TR-99-00468

August 1999

Revision 0

\begin{tabular}{|c|c|c|c|c|c|c|c|}
\hline \multirow[b]{2}{*}{ ID } & \multirow{2}{*}{$\begin{array}{c}\text { Northing } \\
\text { Surface: } \\
102210.73\end{array}$} & \multirow{2}{*}{$\begin{array}{l}\text { Easting } \\
\text { Surface: } \\
48646.11\end{array}$} & \multirow{2}{*}{$\begin{array}{l}\text { Elevation } \\
\text { (ft } \mathrm{msl})\end{array}$} & \multicolumn{4}{|c|}{ Soil Conc. (avg) } \\
\hline & & & & $\begin{array}{c}\text { TCE } \\
\text { (ug/g) }\end{array}$ & $\begin{array}{l}\text { PCE } \\
\text { (ug/g) }\end{array}$ & $\begin{array}{c}\text { TCA } \\
(\mathrm{ug} / \mathrm{g})\end{array}$ & $\begin{array}{c}\mathrm{CCl} 4 \\
(\mathrm{ug} / \mathrm{g})\end{array}$ \\
\hline \begin{tabular}{|l|l|} 
MRS26 & 36
\end{tabular} & 102152.1 & 48576.2 & 266 & 0.148 & 0.092 & $<0.001$ & $<0.001$ \\
\hline \begin{tabular}{|l|l|} 
MRS26 & 37 \\
\end{tabular} & 102151.6 & 48575.7 & 265 & 0.015 & 0.007 & $<0.001$ & $<0.001$ \\
\hline \begin{tabular}{|l|l|} 
MRS26 & 38
\end{tabular} & 102149.4 & 48573.0 & 262 & 22.132 & 54.925 & 0.059 & 0.001 \\
\hline \begin{tabular}{|l|l|} 
MRS26 & 39
\end{tabular} & 102148.9 & 48572.4 & 261 & 0.019 & 0.074 & $<0.001$ & $<0.001$ \\
\hline \begin{tabular}{|l|l|} 
MRS26 & 40
\end{tabular} & 102148.5 & 48571.9 & 261 & $<0.001$ & 0.002 & $<0.001$ & $<0.001$ \\
\hline \begin{tabular}{l|l} 
MRS26 & 41
\end{tabular} & 102148.0 & 48571.4 & 260 & 0.002 & 0.004 & $<0.001$ & $<0.001$ \\
\hline \begin{tabular}{l|l} 
MRS26 & 42
\end{tabular} & 102144.8 & 48567.6 & 255 & 0.379 & 8.493 & $<0.001$ & $<0.001$ \\
\hline \begin{tabular}{|l|l|} 
MRS26 & 43 \\
\end{tabular} & 102144.4 & 48567.0 & 254 & 0.148 & 2.496 & $<0.001$ & $<0.001$ \\
\hline \begin{tabular}{|l|l|} 
MRS26 & 44 \\
\end{tabular} & 102143.9 & 48566.5 & 253 & 0.111 & 0.452 & $<0.001$ & $<0.001$ \\
\hline \begin{tabular}{|l|l|} 
MRS26 & 45 \\
\end{tabular} & 102143.5 & 48565.9 & 253 & 0.003 & 0.017 & $<0.001$ & $<0.001$ \\
\hline \begin{tabular}{|l|l|} 
MRS26 & 46 \\
\end{tabular} & 102143.0 & 48565.4 & 252 & 0.002 & 0.010 & $<0.001$ & $<0.001$ \\
\hline \begin{tabular}{|l|l|} 
MRS26 & 47 \\
\end{tabular} & 102142.6 & 48564.9 & 251 & 0.002 & 0.010 & $<0.001$ & $<0.001$ \\
\hline \begin{tabular}{|l|l|} 
MRS26 & 48 \\
\end{tabular} & 102142.1 & 48564.3 & 251 & 0.003 & 0.012 & $<0.001$ & $<0.001$ \\
\hline \begin{tabular}{|l|l|} 
MRS26 & 49 \\
\end{tabular} & 102141.6 & 48563.8 & 250 & 0.005 & 0.039 & 0.005 & $<0.001$ \\
\hline \begin{tabular}{|l|l|} 
MRS26 & 50 \\
\end{tabular} & 102140.3 & 48562.2 & 248 & 0.082 & 1.199 & $<0.001$ & $<0.001$ \\
\hline \begin{tabular}{|l|l|} 
MRS26 & 51
\end{tabular} & 102139.4 & 48561.1 & 246 & 0.158 & 1.431 & $<0.001$ & $<0.001$ \\
\hline \begin{tabular}{|l|l|} 
MRS26 & 52 \\
\end{tabular} & 102138.5 & 48560.0 & 245 & 0.090 & 2.155 & $<0.001$ & $<0.001$ \\
\hline \begin{tabular}{|l|l|} 
MRS26 & 53
\end{tabular} & 102138.0 & 48559.4 & 244 & 0.052 & 3.779 & 0.005 & $<0.001$ \\
\hline \begin{tabular}{|l|l|} 
MRS26 & 54
\end{tabular} & 102137.6 & 48558.9 & 244 & 0.041 & 23.575 & 0.004 & $<0.001$ \\
\hline \begin{tabular}{|l|l|} 
MRS26 & 55
\end{tabular} & 102137.1 & 48558.4 & 243 & 0.004 & 8.656 & 0.020 & 0.004 \\
\hline \begin{tabular}{|l|l|} 
MRS26 & 56 \\
\end{tabular} & 102136.6 & 48557.8 & 242 & 0.112 & 55.394 & 0.013 & 0.002 \\
\hline \begin{tabular}{|l|l|} 
MRS26 & 57 \\
\end{tabular} & 102136.2 & 48557.3 & 241 & 0.006 & 1.298 & $<0.001$ & 0.012 \\
\hline \begin{tabular}{|l|l|} 
MRS26 & 58 \\
\end{tabular} & 102135.7 & 48556.7 & 241 & 0.480 & 49.306 & 0.025 & 0.015 \\
\hline \begin{tabular}{|l|l|} 
MRS26 & 59 \\
\end{tabular} & 102135.3 & 48556.2 & 240 & 0.144 & 198.307 & 0.008 & 0.002 \\
\hline \begin{tabular}{|l|l|} 
MRS26 & 60 \\
\end{tabular} & 102134.8 & 48555.7 & 239 & $<0.001$ & 0.054 & 0.044 & 0.007 \\
\hline \begin{tabular}{|l|l|} 
MRS26 & 61 \\
\end{tabular} & 102134.4 & 48555.1 & 239 & $<0.001$ & 0.276 & $<0.001$ & 0.006 \\
\hline \begin{tabular}{|l|l|} 
MRS26 & 62
\end{tabular} & 102133.9 & 48554.6 & 238 . & 0.027 & 22.031 & 0.015 & 0.004 \\
\hline MRS26 63 & 102133.5 & 48554.0 & 237 & $<0.001$ & 0.039 & 0.084 & $<0.001$ \\
\hline MRS26 64 & 102133.0 & 48553.5 & 236 & 0.051 & 113.648 & $<0.001$ & $<0.001$ \\
\hline MRS26 65 & 102132.6 & 48552.9 & 236 & 0.006 & 0.946 & 0.716 & $<0.001$ \\
\hline \begin{tabular}{|l|l|} 
MRS26 66
\end{tabular} & 102132.1 & 48552.4 & 235 & 0.040 & 20.802 & $<0.001$ & 0.004 \\
\hline \begin{tabular}{|l|l|} 
MRS2 & 67
\end{tabular} & 102130.7 & 48550.8 & 233 & 0.132 & 47.146 & $<0.001$ & $<0.001$ \\
\hline \begin{tabular}{|l|l|} 
MRS26 & 68
\end{tabular} & 102130.3 & 48550.2 & 232 & 0.095 & 17.319 & 0.004 & $<0.001$ \\
\hline \begin{tabular}{|l|l|} 
MRS26 &
\end{tabular} & 102129.8 & 48549.7 & 232 & 0.081 & 5.986 & $<0.001$ & $<0.001$ \\
\hline \begin{tabular}{|l|l|} 
MRS26 & 70
\end{tabular} & 102129.4 & 48549.2 & 231 & 0.038 & 2.022 & $<0.001$ & $<0.001$ \\
\hline $\mid$\begin{tabular}{|l|l|} 
MRS26 & 71
\end{tabular} & 102128.9 & 48548.6 & 230 & 0.093 & 3.398 & $<0.001$ & $<0.001$ \\
\hline \begin{tabular}{|l|l|} 
MRS26 & 72 \\
\end{tabular} & 102128.5 & 48548.1 & 229 & 0.142 & 6.796 & $<0.001$ & $<0.001$ \\
\hline \begin{tabular}{|l|l|} 
MRS26 & 73
\end{tabular} & 102128.0 & 48547.5 & 229 & 0.074 & 3.026 & $<0.001$ & $<0.001$ \\
\hline \begin{tabular}{|l|l|} 
MRS26 & 74
\end{tabular} & 102126.2 & 48545.4 & 226 & 1.639 & 36.763 & $<0.002$ & $<0.001$ \\
\hline \begin{tabular}{|l|l|} 
MRS26 & 75 \\
\end{tabular} & 102125.3 & 48544.3 & 224 & 0.018 & 0.842 & $<0.001$ & $<0.001$ \\
\hline MRS26 76 & 102124.4 & 48543.2 & 223 & 0.010 & 1.894 & $<0.001$ & $<0.001$ \\
\hline \begin{tabular}{|l|l|} 
MRS26 & 77 \\
\end{tabular} & 102122.1 & 48540.5 & 220 & 0.127 & 7.314 & $<0.001$ & $<0.00$ \\
\hline
\end{tabular}




\begin{tabular}{|c|c|c|c|c|c|c|c|}
\hline \multirow[b]{2}{*}{ ID } & \multirow{2}{*}{\begin{tabular}{|c|} 
Northing \\
\\
Surface: \\
102210.73 \\
\end{tabular}} & \multirow{2}{*}{$\begin{array}{c}\text { Easting } \\
\text { Surface: } \\
48646.11\end{array}$} & \multirow{2}{*}{$\begin{array}{l}\text { Elevation } \\
\text { (ft } \mathrm{msl})\end{array}$} & \multicolumn{4}{|c|}{ Soil Conc. (avg) } \\
\hline & & & & $\begin{array}{c}\text { TCE } \\
(\mathrm{ug} / \mathrm{g})\end{array}$ & $\begin{array}{c}\text { PCE } \\
\text { (ug/g) }\end{array}$ & $\begin{array}{c}\text { TCA } \\
\text { (ug/g) }\end{array}$ & $\begin{array}{c}\mathrm{CCl} / 4 \\
(\mathrm{ug} / \mathrm{g})\end{array}$ \\
\hline \begin{tabular}{|l|l|} 
MRS26 & 78 \\
\end{tabular} & 102121.6 & 48539.9 & 219 & 0.929 & 19.719 & $<0.001$ & $<0.00^{\prime}$ \\
\hline \begin{tabular}{|l|l|} 
MRS26 & 79 \\
\end{tabular} & 1021 & 48 & 218 & 1.016 & 18.469 & $<0.001$ & 0.4 \\
\hline \begin{tabular}{|l|l|} 
MRS26 & 80
\end{tabular} & $\overline{1021}$ & $\overline{485}$ & 217 & 0.936 & 13.975 & $<0.001$ & 0 \\
\hline \begin{tabular}{|l|l|} 
MRS26 & 81 \\
\end{tabular} & 102120.3 & 48538.3 & 217 & 0.174 & 1.420 & $<0.001$ & $<0.00$ \\
\hline \begin{tabular}{|l|l|} 
MRS26 & 82 \\
\end{tabular} & 102119.8 & 48537.8 & 216 & 0.233 & 1.410 & $<0.001$ & 0.0 \\
\hline \begin{tabular}{|l|l|} 
MRS26 & 83 \\
\end{tabular} & 102119.4 & 48537.2 & 215 & 0.689 & 1.639 & $<0.001$ & $<0.00$ \\
\hline \begin{tabular}{|l|l|} 
MRS26 & 84 \\
\end{tabular} & 102 & 48536.7 & 215 & 0.780 & 1.419 & $<0.001$ & $<0.00$ \\
\hline \begin{tabular}{|l|l|} 
MRS26 & 85
\end{tabular} & 102118.5 & 48536.1 & 214 & 0.728 & 2.228 & $<0.001$ & $<0.00$ \\
\hline \begin{tabular}{|l|l|} 
MRS26 & 86 \\
\end{tabular} & 102118.0 & 485 & 213 & 0.227 & 0.945 & $<0.001$ & $<0.00$ \\
\hline \begin{tabular}{|l|l|} 
MRS26 & 87 \\
\end{tabular} & 102117.6 & 48535.1 & 212 & 0.064 & 0.102 & $<0.001$ & $<0.00$ \\
\hline \begin{tabular}{|l|l|} 
MRS26 & 88 \\
\end{tabular} & 102116.6 & 48534.0 & 211 & 0.054 & 0.045 & $<0.001$ & $<0.00$ \\
\hline \begin{tabular}{|l|l|} 
MRS26 & 89 \\
\end{tabular} & 102115.7 & 48532.9 & 210 & 0.132 & 0.571 & $<0.001$ & $<0.00$ \\
\hline \begin{tabular}{|l|l|} 
MRS26 & 90 \\
\end{tabular} & 102114.8 & 48531.8 & 208 & 0.072 & 0.050 & $<0.001$ & $<0.00$ \\
\hline \begin{tabular}{|l|l|} 
MRS26 & 91 \\
\end{tabular} & 102113.0 & 48529.6 & 205 & 0.016 & 0.008 & $<0.001$ & $<0.00$ \\
\hline \begin{tabular}{|l|l|} 
MRS26 & 92 \\
\end{tabular} & 102112.1 & 48528.6 & 204 & 0.013 & 0.002 & $<0.001$ & $<0.00$ \\
\hline \begin{tabular}{|l|l|} 
MRS26 & 93 \\
\end{tabular} & 102111.2 & 48527.5 & 203 & 0.003 & 0.035 & $<0.001$ & $<0.00$ \\
\hline \begin{tabular}{|l|l|} 
MRS26 & 94 \\
\end{tabular} & 102110.3 & 48526.4 & 201 & 0.033 & 0.003 & $<0.001$ & $\angle 0.00$ \\
\hline \begin{tabular}{l|l|l} 
MRS26 & 95 \\
\end{tabular} & 102109.4 & 48525.3 & 200 & 0.023 & $<0.001$ & $<0.001$ & -0.00 \\
\hline
\end{tabular}


Table A-2. Depth Concentration Profile for Boring MRS27. Drilled at a $45^{\circ}$ angle from the south side of the M-Area basin to the center.

\begin{tabular}{|c|c|c|c|c|c|c|c|}
\hline \multirow{2}{*}{\multicolumn{2}{|c|}{ ID }} & \multirow{2}{*}{$\begin{array}{c}\text { Northing } \\
\text { Surface: } \\
101807.95\end{array}$} & \multirow{2}{*}{$\begin{array}{c}\text { Easting } \\
\text { Surface: } \\
48534.44\end{array}$} & \multirow{2}{*}{$\begin{array}{c}\text { Elevation } \\
\text { (ft msl) }\end{array}$} & \multicolumn{3}{|c|}{ Soil Conc. (avg) } \\
\hline & & & & & $\begin{array}{c}\text { TCE } \\
\text { (ug/g) }\end{array}$ & $\begin{array}{c}\text { PCE } \\
\text { (ug/g) }\end{array}$ & $\begin{array}{c}\text { TCA } \\
(\mathrm{ug} / \mathrm{g})\end{array}$ \\
\hline MRS27 & 01 & 101812.2 & 48534.44 & 347 & $<0.001$ & 0.003 & $<0.001$ \\
\hline MRS27 & 02 & 101817.8 & 48534.44 & 342 & $<0.001$ & $<0.001$ & $<0.001$ \\
\hline MRS27 & 03 & 101824.9 & 48534.44 & 335 & 0.002 & 0.015 & 0.003 \\
\hline MRS27 & 04 & 101832.0 & 48534.44 & 328 & 0.002 & 0.011 & 0.002 \\
\hline MRS27 & 05 & 101839.1 & 48534.44 & 320 & $<0.001$ & $<0.001$ & $<0.001$ \\
\hline MRS27 & 06 & 101844.7 & 48534.44 & 315 & $<0.001$ & $<0.001$ & $<0.001$ \\
\hline MRS27 & 07 & 101851.1 & 48534.44 & 308 & $<0.001$ & $<0.001$ & $<0.001$ \\
\hline MRS27 & 08 & 101860.3 & 48534.44 & 299 & $<0.001$ & $<0.001$ & $<0.001$ \\
\hline MRS27 & 09 & 101863.1 & 48534.44 & 296 & $<0.001$ & $<0.001$ & $<0.001$ \\
\hline MRS27 & 10 & 101870.2 & 48534.44 & 289 & $<0.001$ & $<0.001$ & $<0.001$ \\
\hline MRS27 & 11 & 101880.1 & 48534.44 & 279 & $<0.001$ & 0.003 & $<0.001$ \\
\hline MRS27 & 12 & 101885.7 & 48534.44 & 274 & 0.001 & 0.002 & $<0.001$ \\
\hline MRS27 & 13 & 101893.5 & 48534.44 & 266 & $<0.001$ & $<0.001$ & $<0.001$ \\
\hline MRS27 & 14 & 101900.6 & 48534.44 & 259 & $<0.001$ & $<0.001$ & $<0.001$ \\
\hline MRS27 & 15 & 101909.8 & 48534.44 & 250 & $<0.001$ & $<0.001$ & $<0.001$ \\
\hline MRS27 & 16 & 101913.3 & 48534.44 & 246 & $<0.001$ & 0.003 & $<0.001$ \\
\hline MRS27 & 17 & 101916.8 & 48534.44 & 243 & $<0.001$ & $<0.001$ & $<0.001$ \\
\hline MRS27 & 18 & 101923.9 & 48534.44 & 236 & $<0.001$ & 0.002 & $<0.001$ \\
\hline MRS27 & 19 & 101928.2 & 48534.44 & 231 & 0.001 & 0.007 & 0.002 \\
\hline MRS27 & 20 & 101931.0 & 48534.44 & 229 & 0.002 & 0.017 & 0.004 \\
\hline MRS27 & 21 & 101933.8 & 48534.44 & 226 & 0.002 & 0.003 & $<0.001$ \\
\hline MRS27 & 22 & 101935.9 & 48534.44 & 224 & 0.004 & 0.015 & 0.003 \\
\hline MRS27 & 23 & 101938.1 & 48534.44 & 221 & 0.003 & 0.010 & 0.001 \\
\hline MRS27 & 24 & 101940.2 & 48534.44 & 219 & 0.002 & 0.011 & 0.002 \\
\hline MRS27 & 25 & 101943.0 & 48534.44 & 217 & $<0.001$ & 0.001 & $<0.001$ \\
\hline MRS27 & 26 & 101945.8 & .48534 .44 & 214 & $<0.001$ & 0.001 & $<0.001$ \\
\hline MRS27 & 27 & 101947.3 & .48534 .44 & 212 & $<0.001$ & 0.001 & $<0.001$ \\
\hline MRS27 & 28 & 101948.7 & 48534.44 & 211 & 0.002 & 0.010 & 0.002 \\
\hline MRS27 & 29 & 101950.8 & 48534.44 & 209 & $<0.001$ & 0.005 & 0.001 \\
\hline MRS27 & 30 & 101951.5 & 48534.44 & 208 & 0.002 & 0.013 & 0.003 \\
\hline MRS27 & 31 & 101953.6 & 48534.44 & 206 & $<0.001$ & $<0.001$ & $<0.001$ \\
\hline MRS27 & 32 & 101955.0 & 48534.44 & 205 & 0.013 & 0.003 & $<0.001$ \\
\hline MRS27 & 33 & 101955.7 & 48534.44 & 204 & 0.032 & 0.007 & 0.001 \\
\hline MRS27 & 34 & 101956.4 & 48534.44 & 203 & 0.026 & 0.003 & $<0.001$ \\
\hline MRS27 & 35 & 101957.1 & 48534.44 & 202 & 0.018 & 0.004 & 0.001 \\
\hline
\end{tabular}


Table A-3. Depth Concentration Profile for Boring MRS28. Drilled vertically at a location between the M-Area Basin and the In Situ Oxidation Demonstration Location (MOX well series).

\begin{tabular}{|c|c|c|c|c|}
\hline \multirow{2}{*}{ ID } & \multirow{2}{*}{$\begin{array}{c}\text { Elevation } \\
\text { (ft msl) }\end{array}$} & \multicolumn{3}{|c|}{ Soil Conc. (avg) } \\
\hline & & $\begin{array}{c}\text { TCE } \\
\text { (ug/g) }\end{array}$ & $\begin{array}{c}\mathrm{PCE} \\
\text { (ug/g) }\end{array}$ & $\begin{array}{c}\text { TCA } \\
\text { (ug/g) }\end{array}$ \\
\hline \begin{tabular}{|l|l|} 
MRS28 & 01 \\
\end{tabular} & 355 & 0.001 & 0.005 & $<0.001$ \\
\hline \begin{tabular}{|l|l|} 
MRS28 & 02 \\
\end{tabular} & 351 & $<0.001$ & 0.001 & $<0.001$ \\
\hline \begin{tabular}{|l|l|} 
MRS28 & 03 \\
\end{tabular} & 346 & $<0.001$ & $<0.001$ & $<0.001$ \\
\hline \begin{tabular}{|l|l|} 
MRS28 & 04 \\
\end{tabular} & 341 & $<0.001$ & $<0.001$ & $<0.001$ \\
\hline \begin{tabular}{|l|l|} 
MRS28 & 05
\end{tabular} & 335 & $<0.001$ & $<0.001$ & $<0.001$ \\
\hline \begin{tabular}{|l|l|} 
MRS28 & 06 \\
\end{tabular} & 327 & $<0.001$ & $<0.001$ & $<0.001$ \\
\hline \begin{tabular}{|l|l|} 
MRS28 & 07 \\
\end{tabular} & 311 & $<0.001$ & $<0.001$ & $<0.001$ \\
\hline \begin{tabular}{|l|l|} 
MRS28 & 08 \\
\end{tabular} & 304 & $<0.001$ & $<0.001$ & $<0.001$ \\
\hline \begin{tabular}{|l|l|} 
MRS28 & 09 \\
\end{tabular} & 295 & $<0.001$ & $<0.001$ & $<0.001$ \\
\hline \begin{tabular}{|l|l|} 
MRS28 & 10 \\
\end{tabular} & 285 & $<0.001$ & $<0.001$ & $<0.001$ \\
\hline \begin{tabular}{|l|l|} 
MRS28 & 11 \\
\end{tabular} & 274 & $<0.001$ & $<0.001$ & $<0.001$ \\
\hline \begin{tabular}{|l|l|} 
MRS28 & 12 \\
\end{tabular} & 261 & 0.004 & 0.001 & $<0.001$ \\
\hline \begin{tabular}{|l|l|} 
MRS28 & 13 \\
\end{tabular} & 255 & $<0.001$ & $<0.001$ & $<0.001$ \\
\hline \begin{tabular}{|l|l} 
MRS28 & 14
\end{tabular} & 244 & $<0.001$ & $<0.001$ & $<0.001$ \\
\hline \begin{tabular}{|l|l|} 
MRS28 & 15
\end{tabular} & 242 & $<0.001$ & $<0.001$ & $<0.001$ \\
\hline \begin{tabular}{|l|l} 
MRS28 & 16 \\
\end{tabular} & 241 & $<0.001$ & $<0.001$ & $<0.001$ \\
\hline \begin{tabular}{|l|l} 
MRS28 & 17
\end{tabular} & $240:$ & $<0.001$ & $<0.001$ & $<0.001$ \\
\hline \begin{tabular}{|l|l|} 
MRS28 & 18
\end{tabular} & 239 & $<0.001$ & $<0.001$ & $<0.001$ \\
\hline \begin{tabular}{|l|l|} 
MRS28 & 19
\end{tabular} & 238 & $<0.001$ & $<0.001$ & $<0.001$ \\
\hline \begin{tabular}{|l|l|} 
MRS28 & 20 \\
\end{tabular} & 237 & $<0.001$ & $<0.001$ & $<0.001$ \\
\hline \begin{tabular}{|l|l|} 
MRS28 & 21
\end{tabular} & 236 & $<0.001$ & $<0.001$ & $<0.001$ \\
\hline \begin{tabular}{|l|l|} 
MRS28 & 22 \\
\end{tabular} & 235 & $<0.001$ & $<0.001$ & $<0.001$ \\
\hline \begin{tabular}{|l|l|} 
MRS28 & 23 \\
\end{tabular} & 234 & $<0.001$ & $<0.001$ & $<0.001$ \\
\hline \begin{tabular}{|l|l|} 
MRS28 & 24 \\
\end{tabular} & 233 & $<0.001$ & $<0.001$ & $<0.001$ \\
\hline \begin{tabular}{|l|l|} 
MRS28 & 25 \\
\end{tabular} & 232 & $<0.001$ & $<0.001$ & $<0.001$ \\
\hline \begin{tabular}{|l|l|} 
MRS28 & 26 \\
\end{tabular} & 231 & $<0.001$ & $<0.001$ & $<0.001$ \\
\hline \begin{tabular}{|l|l|} 
MRS28 & 27
\end{tabular} & 230 & 0.002 & 0.010 & $<0.001$ \\
\hline \begin{tabular}{|l|l|} 
MRS28 & 28 \\
\end{tabular} & 229 & 0.004 & 0.049 & $<0.001$ \\
\hline \begin{tabular}{|l|l|} 
MRS28 & 29 \\
\end{tabular} & 228 & 0.126 & 1.291 & $<0.001$ \\
\hline \begin{tabular}{|l|l|} 
MRS28 & 30 \\
\end{tabular} & 227 & 1.705 & 12.040 & $<0.001$ \\
\hline \begin{tabular}{|l|l|} 
MRS28 & 31
\end{tabular} & 226 & 1.154 & 11.440 & $<0.001$ \\
\hline \begin{tabular}{|l|l|} 
MRS28 & 32 \\
\end{tabular} & 225 & 0.770 & 2.589 & $<0.001$ \\
\hline \begin{tabular}{|l|l|} 
MRS28 & 33 \\
\end{tabular} & 224 & 1.672 & 10.852 & 0.002 \\
\hline \begin{tabular}{|l|l|} 
MRS28 & 34
\end{tabular} & 223 & 0.671 & 6.469 & 0.001 \\
\hline \begin{tabular}{|l|l|} 
MRS28 & 35 \\
\end{tabular} & 222 & 0.279 & 2.826 & $<0.001$ \\
\hline \begin{tabular}{|l|l|} 
MRS28 & 36
\end{tabular} & 221 & 0.142 & 1.159 & $<0.001$ \\
\hline
\end{tabular}




\begin{tabular}{|c|c|c|c|c|}
\hline \multirow{2}{*}{ ID } & \multirow{2}{*}{$\begin{array}{l}\text { Elevation } \\
\text { (ft } \mathrm{msl})\end{array}$} & \multicolumn{3}{|c|}{ Soil Conc. (avg) } \\
\hline & & $\begin{array}{c}\mathrm{TCE} \\
\text { (ug/g) }\end{array}$ & $\begin{array}{l}\text { PCE } \\
\text { (ug/g) }\end{array}$ & $\begin{array}{c}\text { TCA } \\
\text { (ug/g) }\end{array}$ \\
\hline \begin{tabular}{l|l} 
MRS28 & 37 \\
\end{tabular} & 220 & 0.012 & 0.045 & $<0.001$ \\
\hline \begin{tabular}{|l|l|} 
MRS28 & 38
\end{tabular} & 219 & 0.014 & 0.115 & $<0.001$ \\
\hline \begin{tabular}{|l|l|} 
MRS28 & 39 \\
\end{tabular} & 218 & 0.218 & 5.433 & 0.001 \\
\hline \begin{tabular}{|l|l|} 
MRS28 & 40
\end{tabular} & 217 & 0.141 & 2.539 & $<0.001$ \\
\hline \begin{tabular}{|l|l|} 
MRS28 & 41
\end{tabular} & 216 & 0.264 & 3.535 & $<0.001$ \\
\hline \begin{tabular}{|l|l} 
MRS28 & 42
\end{tabular} & 215 & 0.434 & 3.331 & 0.001 \\
\hline \begin{tabular}{|l|l} 
MRS28 & 43 \\
\end{tabular} & 214 & 0.327 & 2.464 & 0.001 \\
\hline \begin{tabular}{|l|l} 
MRS28 & 44 \\
\end{tabular} & 213 & 0.145 & 1.617 & $<0.001$ \\
\hline \begin{tabular}{|l|l|} 
MRS28 & 45 \\
\end{tabular} & 212 & 1.293 & 6.056 & $<0.001$ \\
\hline \begin{tabular}{|l|l} 
MRS28 & 46
\end{tabular} & $\overline{211}$ & 0.728 & 5.913 & $<0.001$ \\
\hline \begin{tabular}{|l|l|} 
MRS28 & 47 \\
\end{tabular} & 210 & 1.704 & 9.376 & $<0.001$ \\
\hline \begin{tabular}{|l|l|} 
MRS28 & 48 \\
\end{tabular} & 209 & 1.806 & 7.178 & $<0.001$ \\
\hline \begin{tabular}{|l|l|} 
MRS28 & 49 \\
\end{tabular} & 208 & 1.917 & 7.551 & $<0.001$ \\
\hline \begin{tabular}{|l|l} 
MRS28 & 50 \\
\end{tabular} & 207 & 0.633 & 2.185 & $<0.001$ \\
\hline \begin{tabular}{|l|l} 
MRS28 & 51
\end{tabular} & 206 & 0.194 & 0.352 & $<0.001$ \\
\hline \begin{tabular}{|l|l|} 
MRS28 & 52 \\
\end{tabular} & 205 & 0.052 & 0.121 & $<0.001$ \\
\hline \begin{tabular}{|l|l|} 
MRS28 & 53 \\
\end{tabular} & 204 & 0.093 & 0.121 & $<0.001$ \\
\hline \begin{tabular}{|l|l|} 
MRS28 & 54 \\
\end{tabular} & 203 & 0.051 & 0.031 & $<0.001$ \\
\hline \begin{tabular}{|l|l} 
MRS28 & 55 \\
\end{tabular} & 202 & 0.019 & 0.007 & $<0.001$ \\
\hline \begin{tabular}{|l|l|} 
MRS28 & 56 \\
\end{tabular} & 201 & 0.041 & 0.015 & $<0.001$ \\
\hline
\end{tabular}

